Article

\title{
Sanitation in Mexico: An Overview of Its Realization as a Human Right
}

\author{
Vanesa García-Searcy ${ }^{1}\left(\mathbb{D}\right.$, Mariana Villada-Canela ${ }^{1, *(D)}$, María Concepción Arredondo-García ${ }^{2}(\mathbb{D}$, \\ Marisol Anglés-Hernández ${ }^{3}{ }^{\mathbb{C}}$, María Candelaria Pelayo-Torres ${ }^{4}$ and Luis Walter Daesslé ${ }^{1}(\mathbb{D}$
}

Citation: García-Searcy, V.;

Villada-Canela, M.;

Arredondo-García, M.C.;

Anglés-Hernández, M.;

Pelayo-Torres, M.C.; Daesslé, L.W.

Sanitation in Mexico: An Overview

of Its Realization as a Human Right.

Sustainability 2022, 14, 2707. https://

doi.org/10.3390/su14052707

Academic Editors: Sayed

Mohammad Nazim Uddin and

Chad Staddon

Received: 29 January 2022

Accepted: 23 February 2022

Published: 25 February 2022

Publisher's Note: MDPI stays neutral with regard to jurisdictional claims in published maps and institutional affiliations.

Copyright: () 2022 by the authors Licensee MDPI, Basel, Switzerland. This article is an open access article distributed under the terms and conditions of the Creative Commons Attribution (CC BY) license (https:// creativecommons.org/licenses/by/ $4.0 /)$.
1 Instituto de Investigaciones Oceanológicas, Universidad Autónoma de Baja California, Carr. Transpeninsular 3917, Ensenada 22860, BC, Mexico; garcia.vanesa@uabc.edu.mx (V.G.-S.); walter@uabc.edu.mx (L.W.D.)

2 Facultad de Ciencias Marinas, Universidad Autónoma de Baja California, Carr. Transpeninsular 3917, Ensenada 22860, BC, Mexico; conchita@uabc.edu.mx

3 Instituto de Investigaciones Jurídicas, Universidad Nacional Autónoma de México, Circuito Maestro Mario de la Cueva s/n, Ciudad Universitaria, Coyoacán 04510, CDMX, Mexico; mangles@unam.mx

4 Facultad de Derecho, Universidad Autónoma de Baja California, Blvd. Benito Juárez and Ave. Ignacio López Rayón s/n, Mexicali 21280, BC, Mexico; candelaria.pelayo@uabc.edu.mx

* Correspondence: mvilladac@uabc.edu.mx; Tel.: +52-646-152-8217

\begin{abstract}
Adequate sanitation is essential for health, human well-being, the preservation of water resources, biodiversity, and the full enjoyment of human rights. Sanitation is a human right, and although it is linked to the human right to water (HRW), it has specific characteristics that deserve particular attention. These components are (1) availability; (2) quality; (3) physical accessibility; (4) affordability; (5) acceptability; (6) equality and non-discrimination; (7) government management and inter-institutional coordination; (8) access to information and participation; and (9) environmental protection. These components enable the analysis of other aspects that may not be fully considered from the traditional sanitation approach. This research aims to analyze the context of the realization of the human right to sanitation (HRS) in Mexico, for a future comprehensive assessment. The study was conducted through documentary and national news coverage research. It concluded that there are still significant challenges to realizing this human right in Mexico. Findings suggest that besides the infrastructure and pollution difficulties, there are other problems like physical and economic access to sanitation for the vulnerable population, inequality between urban and rural areas, the lack of maintenance work of sanitation infrastructure, and the lack of effective coordination between the authorities responsible for sanitation.
\end{abstract}

Keywords: environment; health; human rights; pollution; public policy; sanitation; vulnerable population; water governance; wastewater

\section{Introduction}

Sanitation is a recognized international [1-3] and national [4] human right. It is defined as a process that includes access to sanitation facilities, collection, transport, treatment, and disposal or reuse of domestic wastewater (human excreta and greywater) and the associated hygiene [3,5].

The lack of access to sanitation services and inadequate wastewater management have severe consequences for human health and well-being, water resources, and biodiversity [6-8]. It can be an obstacle to the economic growth of a country [9] and the realization of other human rights [3].

Sanitation is also included in the Sustainable Development Goal No. 6 (SDG6) of the 2030 Agenda [10], which establishes the purpose to ensure the availability and sustainable management of water and sanitation for all. Specifically on sanitation, the states members of the international community have set themselves Goal 6.2 "Achieve access to adequate and equitable sanitation and hygiene services for all, and end open defecation, with special 
attention to people in vulnerable situations"; and Goal 6.3 "Improve water quality by reducing pollution, eliminating dumping and, among others, halving the percentage of untreated wastewater [11].

These goals have contributed to redefining the goals and aligning public policies on sanitation in Mexico [9] and the world. Therefore, the SDG6 require a combination of monitoring methods and adequate governance.

Some approaches to determining its progress or improvement are based on sustainability aspects (environmental, social, and economic issues) [12,13]. However, other approaches can be used for the same purpose. Human rights-based approaches produce the essential conditions for sustainable development [14]. International human rights principles and standards are reflected in the SDG [15].

The human right to sanitation (HRS) contains functional elements to estimate its level of implementation and progress. According to the report A/HRC/12/24 of the United Nations Human Rights Council, these criteria-sometimes called descriptors, content, elements, or components-are availability, quality, physical accessibility, affordability, and acceptability [1]. In addition, other essential components to consider are: the principle of equality and non-discrimination, government management and inter-institutional coordination, access to information and public participation, and environmental protection $[1,2,5,16]$.

Although the HRS is linked to the human right to water (HWR), its autonomy has been recognized, since it has specific characteristics that deserve particular attention [17-19]. However, the trend has been to include the HRS within the HRW and focus on this last one [19]. This situation scatters attention, and the development of actions addressed to the HRS.

In Mexico, there are serious problems associated with sanitation. The national coverage of municipal wastewater treatment is 65.7\% [20]. Moreover, combined (municipal and industrial) wastewater treatment is estimated to be only $49.1 \%$ [21]. In terms of management, it has been warned that there is no proper coordination between the different institutions and authorities involved in water and sanitation management, and wastewater discharge regulations are not adequately enforced [22]. Furthermore, sanitation in Mexico has raised concerns in the social dimension, as marginalized groups (homeless people, women and girls, indigenous communities, and people living in rural areas) are negatively affected [23].

This article focuses its attention on the HRS. It aims to provide an overview of the realization of the human right to sanitation in Mexico, on target toward achieving sanitation national and international goals. It combines official information with the perspective of the national press that portrays the most recurrent social problems on sanitation and attempts to capture the context of sanitation in Mexico as a human right in our path to future research in evaluating sanitation as a human right with a comprehensive quantitative method.

The study is structured as follows: (1) methods, which consisted of documentary and national news coverage research to identify sanitation problems in Mexico; (2) results and discussion (which is divided into general results of the investigation, and specific results by each element of the HRS); and (3) a conclusion.

\section{Methods}

This study was conducted through documentary research [24,25], using a mixed qualitative-quantitative methodology [26]. We analyzed two different sources of information: official data and news coverage (for relevant qualitative information).

Specialized literature on sanitation in Mexico, national legal documents, government reports, and data from the 2020 Population and Housing Census were examined. Sixty-two relevant documents on sanitation were found (Figure 1), reviewed, and classified. 
Government reports and publications of national autonomous bodies

Legal documents (laws, decrees, official Mexican regulations)

Reports or resolutions of international organizations

Scientific publications and specialized bibliography

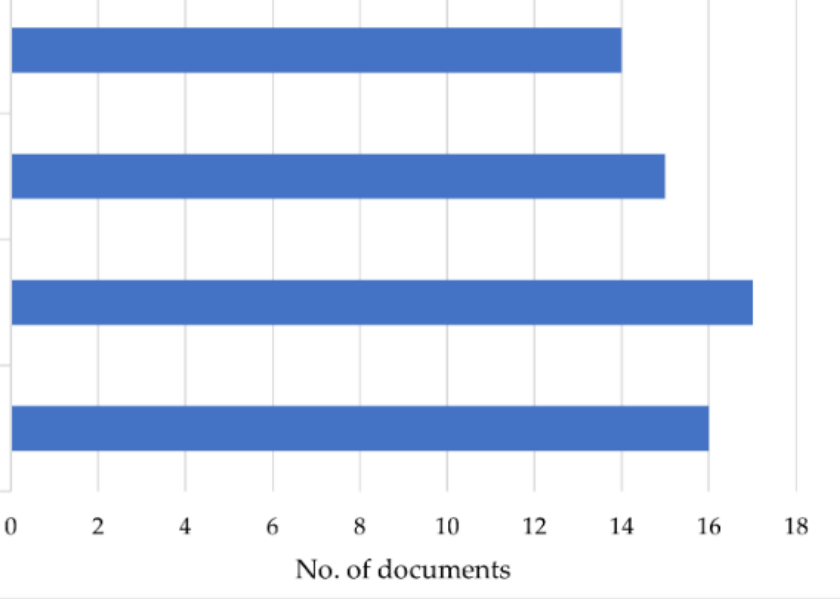

Figure 1. Documentary research on sanitation and human right to sanitation (HRS).

The content of the human rights obligations related to sanitation presented in this paper (availability, quality, physical accessibility, affordability, acceptability, equality and non-discrimination, government management and inter-institutional coordination, access to information and public participation, and environmental protection) entails some flexibility. First, because it is not an exhaustive list, and there may be other criteria that can be adhered to in this content [1]. Secondly, some components can be understood in different ways, depending on the reader's perspective, leading in overlapped content due to their complementary nature (after all, the classification is unimportant as long as full compliance with its content is guaranteed) [1]. However, this classification is helpful for the systematization and the analysis of the human right to sanitation (HRS).

For this investigation, the first step was to identify and describe the content of the human right to sanitation-which constitutes the characteristics to understand the idea of the analyzed objects-based on official United Nations documents [1,2,5,16] (Table 1).

For each component of the HRS [12], we identified some available and reliable preestablish official indicators which may not be explicitly addressed to evaluate the HRS but some aspects of sanitation. However, these indicators are helpful to analyze the situation of specific aspects related to this human right in the country.

Some of the components of the HRS can be fully or partly assessed with quantitativealready developed-official indicators. However, qualitative data are used in human rights because all relevant information and its expression in narrative terms are potentially helpful [27].

For the reason mentioned above, this study includes information presented in sanitationrelated news coverage in Mexico. The journalistic research is limited in that it considers only news coverage of national newspapers, which may result in underrepresented information, especially for small communities or cities where the national newspapers are not very present. However, news information is relevant in identifying the problems afflicting our community and environment, and it can notice actors, causality, and even the prevention of events in society [28]. In the case of this study, it helped to identify some specific sanitation concerns that are hardly distinguished by only analyzing official data. For this purpose, news stories on sanitation in Mexico were reviewed at six national newspapers websites (El Economista, El Financiero, La Jornada, El Universal, Excélsior, and Milenio). The search period was from January 2018 to February 2021. The keywords used for the search were: wastewater, sewage, drainage, coliforms, feces, treatment plants, enterococci, septic tanks, and sanitation. Initially, 234 news stories were found associated with sanitation in Mexico. Repeated items were removed to identify qualified news stories, leaving 206 for the study (Figure 2). Stories were classified by specific topic and by state. 
Table 1. Brief description of the content of the HRS.

Criteria Description

\section{Availability}

2. Quality
It implies that sanitation facilities (with the associated services) are available to everyone and in sufficient number (for this study, we focus on the availability of the infrastructure-sanitation services, sewerage networks, and WWTP).

It focuses on the correct functioning and adequate maintenance of the available infrastructure (sanitation services, sewerage networks, and WWTP). It includes complying with the regulatory framework and avoiding direct contact with human excrements or greywater and its safe disposal.

In terms of human rights, it implies adequate access to sanitation facilities for all, in each household, immediate vicinity or public spaces, all times of day and night. The sanitation facilities and the path leading to them must ensure minimal risk to the physical security of users. It includes sanitation facilities be designed to enable people with special access needs and marginalized groups to access them physically. It also implies access to sanitation to people living in remote places (rural areas) where sewerage connections are costly and challenging to implement.

4. Affordability

It means that access to sanitation facilities and services must be available at an affordable price for all people. It includes sewerage systems and on-site sanitation, where sewerage usually is unavailable.

Sanitation solutions must be adapted to the social and cultural acceptability of the different regions (privacy, separate facilities for women and men in public places, hygiene practices, and the absence of sewerage odors).

Sanitation must be accessible, especially for the vulnerable and marginalized population (people living in poverty conditions, migrants, indigenous people, refugees, inmates and detainees, people with disabilities, women, children, older adults, people affected with health conditions, and people living in remote areas).

7. Government management and inter-institutional coordination

States must clearly assign institutional responsibilities for sanitation at all levels, and proper coordination must be ensured.

States must have adequate, precise, updated, and detailed information on sanitation coverage in the country. Likewise, each person has the right to participate in the decision-making process that affects their rights to water and sanitation.

8. Access to information and public participation

Everyone has the right to access an adequate and safe sanitation service that protects public health and the environment.

\section{Environmental protection}

$=$ El Economista $=$ El Financiero
$=$ El Universal $\quad=$ Excélsior
$=$ La Jornada $\quad=$ Milenio

Figure 2. News coverage on sanitation in Mexico by source. 
Finally, with the combination of official data and news coverage, we arrived at a descriptive analysis result. Descriptive analysis is a necessary resource for the social sciences and humanities [29].

\section{Results and Discussion}

Official information related to sanitation was identified and classified according to the content of the human right to sanitation (HRS) (Table 2).

Table 2. Official data available on sanitation by the content of the HRS.

\begin{tabular}{|c|c|c|c|}
\hline Components of the HRS & $\begin{array}{l}\text { Official Data Related to Sanitation in Mexico } \\
\text { (Pre-Established Indicators) }\end{array}$ & Source & Data \\
\hline \multirow{5}{*}{ Availability } & $\begin{array}{l}\text { Population in occupied housing units with } \\
\text { access to a toilet or latrine }\end{array}$ & INEGI $^{a}$ & $98.1 \%$ \\
\hline & $\begin{array}{l}\text { Population connected to public sewerage } \\
\text { network or septic tank }\end{array}$ & INEGI & $93.8 \%$ \\
\hline & $\begin{array}{l}\text { Number of municipal wastewater treatment } \\
\text { plants (WWTP) }\end{array}$ & CONAGUA $^{\mathrm{b}}$ & $\begin{array}{c}\text { From } 595 \text { WWTP in } 1996 \text { to } 2642 \\
\text { WWTP in } 2019\end{array}$ \\
\hline & Treated wastewater & CONAGUA & $\begin{array}{c}\text { From 33,745.4 L/s in } 1996 \text { to } \\
141,479 \mathrm{~L} / \mathrm{s} \text { in } 2019\end{array}$ \\
\hline & $\begin{array}{l}\text { 5. Percentage of municipal wastewater } \\
\text { collected through sewerage systems treated }\end{array}$ & CONAGUA & $65.7 \%$ \\
\hline \multirow{4}{*}{ Quality } & $\begin{array}{l}\text { Population with flush or pour-flush toilet } \\
\text { facilities }\end{array}$ & INEGI & $95.8 \%$ \\
\hline & $\begin{array}{l}\text { 7. Mortality rate from diarrheal diseases in } \\
\text { children under five years old (per 100,000 } \\
\text { children under five years old) }\end{array}$ & CONAGUA & From 122.7 in 1990to 7.3 in 2015 \\
\hline & 8. Percentage of WWTP in operation & CONAGUA & $72.2 \%$ \\
\hline & $\begin{array}{l}\text { 9. Percentage of surface water and } \\
\text { groundwater that comply with official } \\
\text { quality parameters }\end{array}$ & CONAGUA & $63 \%$ \\
\hline $\begin{array}{l}\text { Physical } \\
\text { accessibility }\end{array}$ & $\begin{array}{l}\text { 10. Toilets with adaptations for people with } \\
\text { disabilities in social assistance shelters for } \\
\text { vulnerable groups, with adaptations for } \\
\text { people with disabilities * }\end{array}$ & INEGI & $32.3 \%$ \\
\hline Affordability & No related indicators found & CNDH-IMTA $^{c}$ & - \\
\hline Acceptability & $\begin{array}{l}\text { 11. Population with exclusive household toilet } \\
\text { facility * }\end{array}$ & INEGI & $91.78 \%$ \\
\hline \multirow{2}{*}{$\begin{array}{c}\text { Equality and } \\
\text { non-discrimination }\end{array}$} & $\begin{array}{l}\text { 12. Population connected to public sewerage } \\
\text { network in rural areas (compared to the } \\
\text { population in urban areas connected to } \\
\text { public sewerage network) }\end{array}$ & INEGI & $32.1 \%$ (and $89.6 \%$ in urban areas) \\
\hline & $\begin{array}{l}\text { 13. Indigenous population with sewerage } \\
\text { network coverage (in 2015) (compared to the } \\
\text { total population with sewerage network) }\end{array}$ & INPI $^{d}$ & $\begin{array}{l}73.1 \% \text { (and } 93.1 \% \text { in total } \\
\text { population) }\end{array}$ \\
\hline
\end{tabular}


Table 2. Cont.

\begin{tabular}{|c|c|c|c|}
\hline Components of the HRS & $\begin{array}{l}\text { Official Data Related to Sanitation in Mexico } \\
\text { (Pre-Established Indicators) }\end{array}$ & Source & Data \\
\hline $\begin{array}{l}\text { Government management and } \\
\text { inter-institutional coordination }\end{array}$ & $\begin{array}{l}\text { 14. Indicator 6.5.1 "Degree of integrated water } \\
\text { resources management implementation" of } \\
\text { the Sustainable Development Goals (SDG) in } \\
\text { Mexico (which includes water and sanitation) } \\
\text { 2.1b Cross-sectoral coordination }\end{array}$ & IWRM $^{\mathrm{e}}$ data portal & $\begin{array}{l}\text { Mexican authorities were at a } \\
\text { medium-low level }\end{array}$ \\
\hline
\end{tabular}

15. Indicator 6.5.1 "Degree of integrated water resources management implementation" of the SDG in Mexico (which includes water and sanitation) 2.1c Public Participation in

Access to information and public participation
16. Indicator 6.5.1 "Degree of integrated water resources management implementation" of the SDG in Mexico (which includes water and sanitation) 2.2c Participation of vulnerable groups
IWRM data portal Low level
17. Municipal and industrial wastewater adequately treated
INEGI

$49.1 \%$

Environmental protection

18. Water bodies in the country classified as having a "good" water quality status

INEGI

$52.9 \%$

Notes: * These indicators cannot be used to evaluate the whole component in which they are classified, official data and other indicators are missing for that purpose. ${ }^{a}$ National Institute of Statistics and Geography; ${ }^{b}$ National Water Commission; ${ }^{c}$ National Human Rights Commission-Mexican Institute of Water Technology; ${ }^{\mathrm{d}}$ National Institute of Indigenous Peoples; ${ }^{\mathrm{e}}$ Integrated Water Resources Management.

On the other hand, results of the analysis of news coverage on sanitation were as follows: Of the universe of news coverage on sanitation (206), 140 stories corresponded to problems and 66 to public responses (positive actions, mainly authority's actions aimed at solving sanitation problems). Many news items centered on quality (concerning the poor functioning of the sanitation infrastructure) and environmental protection (pollution problems associated with sanitation). On the other hand, few stories were associated with affordability, physical accessibility, and equality and non-discrimination (Figure 3).

The 140 stories associated with sanitation problems were grouped into five categories, highlighting that $51 \%$ reported pollution problems in water bodies, $19 \%$ poor sanitation services, malfunctions, and irregularities, and 18\% sewage overflows due to dysfunctional infrastructure (Figure 4).

News coverage on sanitation problems in Mexico was more present in some cities and regions than others. The most mentioned cases were in the state of Guerrero, with 17 news stories (almost half were related to pollution due to wastewater discharges on the coast of Acapulco). Secondly, the state of Coahuila reported 16 stories, which alluded to the continuous sewage overflows and leaks in the municipalities of Torreón and Matamoros, due to the decaying and outdated sanitation infrastructure. In the same way, in the State of Mexico, the quality of infrastructure and sewerage systems that cause wastewater overflows and pollution were the most discussed problems present in news coverage. More detailed information is shown in Appendix A Table A1. 


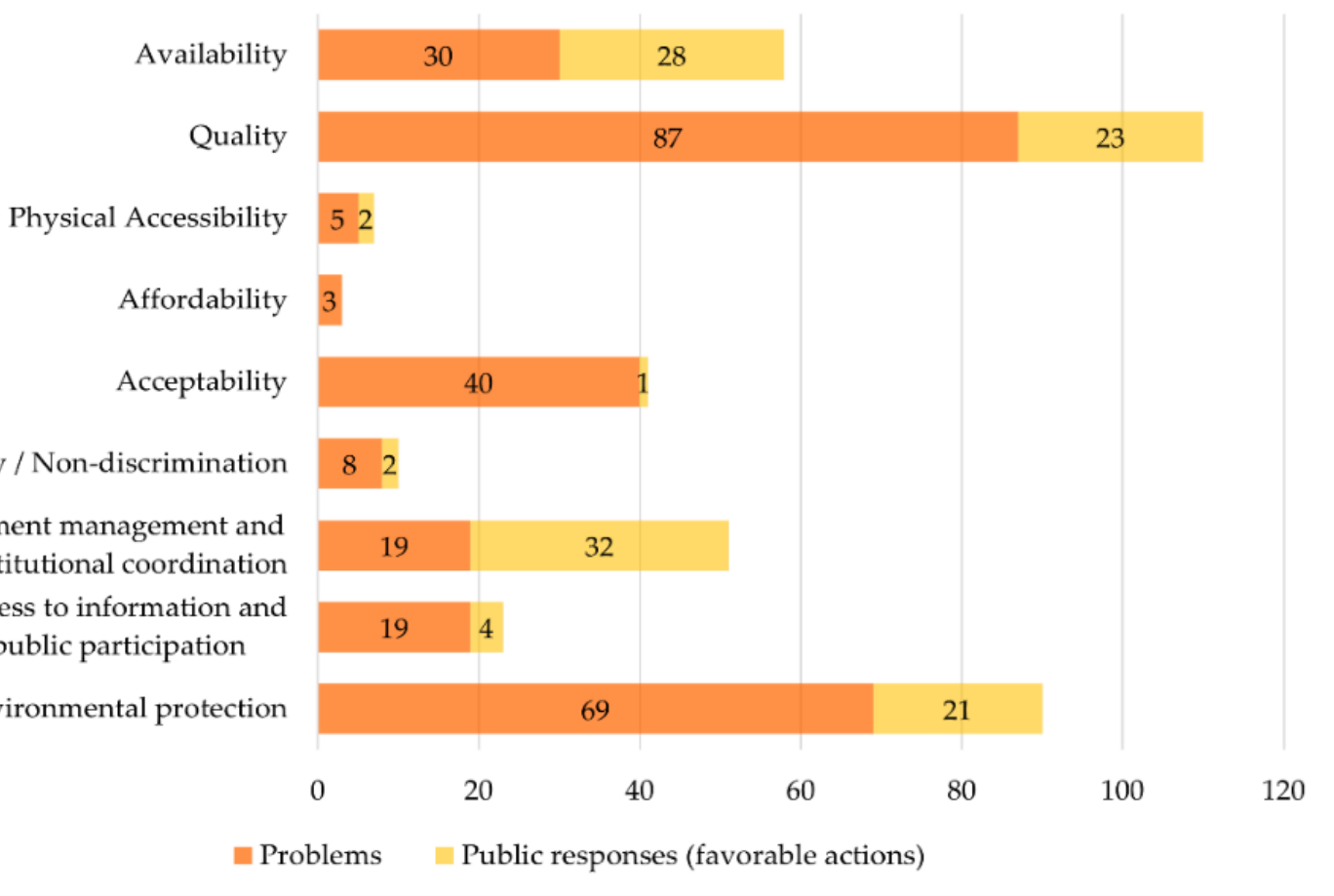

Figure 3. News coverage on sanitation by content associated with the components of the HRS.

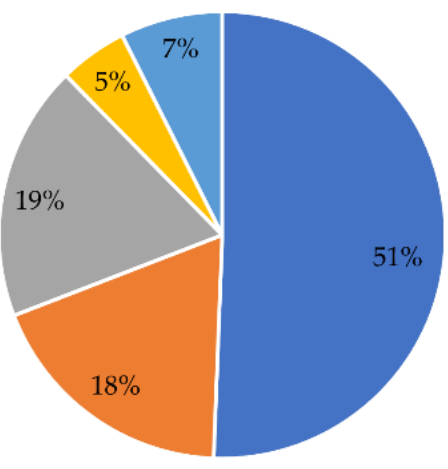

- Contamination of water bodies and damage to the ecosystems

- Sewage spills and floods due to poor wastewater infrastructure

- Poor sanitation services, malfunctions, and irregularities

- Citizen demonstrations, protests, blockades, and complaints

- Irregular sewage discharges due to the proliferation of human settlements (real estate and tourism developments)

Figure 4. News coverage on sanitation problems in Mexico.

On the other hand, national news coverage on sanitation also reported public responses: government actions that seek to solve the problems presented. The 66 news stories related to public responses on sanitation were classified into eight categories. According to data, $30 \%$ of the actions associated with works and investment in sanitation, and $25 \%$ with fines, penalties, or complaints related to sanitation issues (Figure 5). 


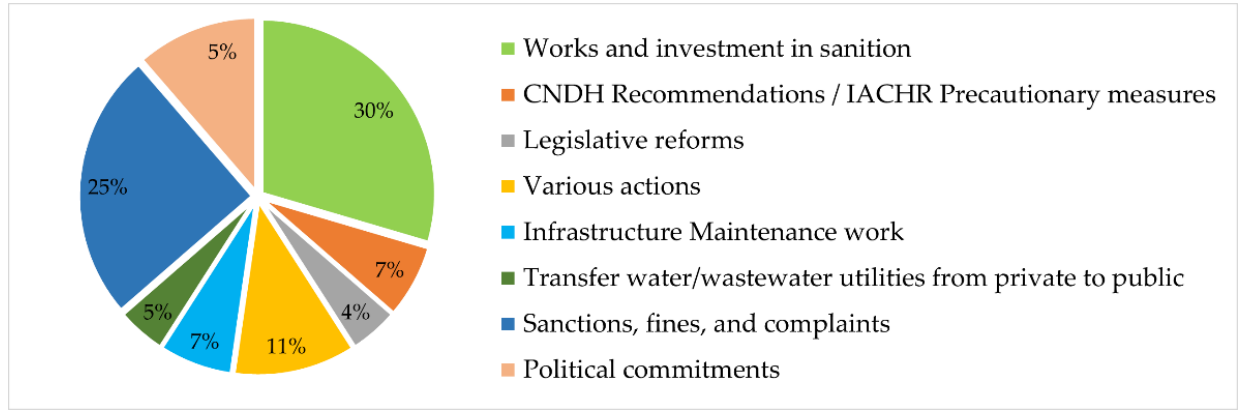

Figure 5. News coverage on public responses related to sanitation in Mexico.

The most represented components of the HRS in news coverage on public responses related to sanitation were: government management and inter-institutional coordination, infrastructure maintenance to guarantee the availability and quality of sanitation services, and actions to improve environmental protection. The states with the highest number of news items associated with public responses on sanitation were Jalisco, Tamaulipas, State of Mexico, and Mexico City (Appendix A Table A2).

With the combination of both official data and news coverage analysis, we arrived at the following results on the situation of the HRS in Mexico and some consideration for a future comprehensive quantitative evaluation (Table 3). For detailed information, see each component section analysis after this table.

Table 3. Summary of the results on the situation of the HRS in Mexico and some considerations.

Content of the HRS

1. Availability

\section{Summary of the Analysis}

Despite the progress in sewerage coverage in recent decades, $1.4 \%$ of the population still discharges their sewage directly into ravines, cracks, rivers, lakes, and the sea; $4.5 \%$ do not have any drainage. In addition, although the number of WWTP has considerably increased, $65.7 \%$ of the municipal wastewater and $49.1 \%$ of the combined municipal and industrial wastewater generated are treated.

According to the news coverage, availability was the third sanitation topic during the analysis period (58 news items found). The lack of infrastructure, or its poor condition, is reflected in the national news coverage, which exhibits sewage overflows in urban areas, unfinished works, or the abandonment of sanitation infrastructure. Other documented problems are the lack of surveillance for compliance with the sanitation regulatory framework and the lack of training for the construction of drainage systems such as septic tanks in areas without sewerage coverage.

For future indicators, it would be important to consider both water-based sanitation systems infrastructure and on-site sanitation infrastructure.

The increase in the sewerage network has reduced water-borne diseases. However, acute diarrheal diseases are still the second cause of death in children under five years old, and intestinal infectious diseases are among the top ten medical emergency conditions. Furthermore, more than a million people in the country only have access to latrines, of which $91.3 \%$ do not work with water. Approximately $88 \%$ of diarrheal diseases are caused by a lack of sanitation, hygiene, and water.

On the other hand, the infrastructure increase is not enough to improve sanitation if adequate maintenance works do not follow. Quality was the first sanitation topic in the news coverage during the analysis period. There were found 110 news items on sanitation quality $(79 \%$ problems $/ 21 \%$ public responses). News coverage documented cases at the national level of spills, leaks, floods, and sewage overflows due to sewerage systems in poor condition in the country. In addition, the malfunctioning of treatment plants that pollute the Mexican coasts is exhibited in some national news stories, as well as the damage to ecosystems and to some economic activities.

For future indicators, it would be important to consider hygiene in the sense of avoiding direct contact with human excrements (specially in sanitation facilities with on-site sanitation systems) but also people's contact with wastewater from sewage overflows or leaks derived from waterborne sanitation systems in poor conditions in urban areas. 
Table 3. Cont.

Content of the HRS

3. Physical accessibility
Summary of the Analysis

Very little information was found related to the physical accessibility of sanitation (both official data and news coverage). We found that in Mexico, 5.9\% of the population has some disability or limitation to walk, go up or down, which implies that, if the sanitation services (in public places and homes) do not have the necessary access, they could have violated their right to sanitation. We also found that $32.3 \%$ of the social assistance shelters in Mexico have toiles with adaptations for people with disabilities.

On the other hand, seven news items were found related to the topic - most of them related to the limitations of sanitation services in rural areas-National news coverage presented cases of communities in Mexico without access to sewerage networks, which led to the proliferation of latrines or septic tanks, many of which are poorly designed and lack hygienic conditions. Furthermore, some national news stories highlighted the two recommendations issued by the National Human Rights Commission (Comisión Nacional de Derechos Humanos: CNDH), arguing that some municipalities have failed to comply with the criteria of accessibility to these public services.

Other than that, we did not identify additional information. Useful official data are missing regarding other aspects of physical accessibility, such as the number of people with special access needs that have access to special sanitation facilities, the access to sanitation in public places like schools or workplaces, or the number of people that have access to secure sanitation facilities day and night. Indicators of these mentioned aspects would be required for a HRS assessment.

Concerning the affordability of sanitation, the municipalities are responsible for the provision of water and sanitation services. Each one fixes its rates under its state legislation (which, for study purposes, generates the difficulty of standardizing and comparing the water and sanitation rates in the country). We assume that this situation could create inequity and social problems among states and municipal entities with high poverty levels.

On the other hand, few news items were found about the affordability of sanitation. However, they reported high water and sanitation services charges despite the services' deficiency. Some communities' lack of sewerage networks forces the population to use latrines or septic tanks with maintenance and emptying elevated costs. There was no available official information related to the affordability of on-site sanitation, such as subsidies for the construction of on-site sanitation facilities or for emptying the receptacles for the collection of human waste, although $16.9 \%$ of the population in Mexico have pits or septic tanks.

There is little official information on this topic; however, it is estimated that toilets' exclusive or shared use is an important element to consider regarding sanitation acceptability and hygiene. In Mexico, $91.78 \%$ of the population have access to a toilet for exclusive use, and $8.15 \%$ have access to shared toilet facilities. On the other hand, the Special Rapporteur on the human rights to safe drinking water and sanitation on his mission to Mexico, has emphasized that, in Mexico, for rural communities with an indigenous population, sanitation is not being adequate since these communities have their cultural practices, which must be considered and respected in public policies and programs.

There were found 41 news items related to this subject. Some news stories indicate the limitations of acceptable sanitation in Mexico. News analysis suggests that the main problem for sanitation acceptability in Mexico (at least in urban areas) is the sewage odors spread due to the malfunction of the sanitation systems, overflows, and leaks of wastewater mainly in urban areas, and odors originated by untreated wastewater discharges on beaches, rivers, lakes, or dams.

No official information was found related to problems with privacy or sewage odors. This information would be desirable for a comprehensive study of the HRS. 
Table 3. Cont.

Content of the HRS

6. Equality and non-discrimination

\section{Summary of the Analysis}

Inequality is evident when it comes to rural and urban settlements. Public policies on sanitation are concentrated on water-based sanitation systems connected to the public sewerage network. While in urban areas, the sewerage network's coverage is $89.6 \%$, in rural areas is only $32.1 \%$. Likewise, the rural population that does not have sewerage connections is $16.4 \%$, while the urban population lacking this service is around $1.2 \%$. On the other hand, generally, on-site sanitation is unplanned, informal, and poorly regulated.

Sanitation inequalities are also embedded in marginalized groups' difficulties. In 2015, at the national level, sewerage coverage was $93.1 \%$, while in the case of indigenous population households, only $73.1 \%$ were connected to sewerage networks. There were only ten news items found related to equality and non-discrimination on sanitation. Most of them were related to rural areas' problems and indigenous groups.

However, there was no specific information regarding other vulnerable groups like children, women, older adults, people with disabilities, people affected with health conditions. Furthermore, information regarding migrants, refugees, inmates, and detainees would have been desirable for a more specific study.

In terms of sanitation, different institutions (government agencies) and levels of government are involved. According to indicator SDG6.5.1 (2.1b Cross-sectoral coordination), in 2020, the Mexican authorities were at a medium-low level, meaning that they have an explicit mandate to coordinate the implementation of Integrated Water Resources Management (IWRM) (which includes water and sanitation) and the capacity to guide the formulation of plans. However, there is still a lack of progress to conduct IWRM plans and their monitoring, evaluation, and adjustments. For further study, it would be desirable to find or develop a cross-sectoral coordination indicator only for sanitation aspects.

Despite enough regulation attempts to coordinate water and sanitation government responsibilities, joint decisions by many authorities in Mexico make water and sanitation management a slow and challenging task. Furthermore, delays and complications also arise due to differences in priorities and financial capabilities between the authorities.

There were found 51 news items related to this topic. The results of the national news analysis reflected 21 public responses, many stories reporting infrastructure investment, and sanctions and fines to authorities. However, we also found 19 news items related to problems such as the lack of compromise by the authorities to assume responsibilities and solve the problems, the possible law violations on water and sanitation services, the lack of regulation of human settlements, and the limitations to the actions of the institutions.

For a further quantitative evaluation of the HRS it would be desirable to consider aspects such as the legal framework for the sanitation-related authorities' respnsabilities, the authorities involved in sanitation management and their level of compliance with their respective obligations on sanitation, or the identification of specific jurisdictional problems.

For this component, there were found two official (international) indicators. Results of indicator SDG6.5.1 (2.1c Public Participation in WRM-national and 2.2c Participation of vulnerable groups) in Mexico 2020, estimates that some mechanisms have been established to facilitate participation in the public sphere in terms of water and sanitation. However, it has been also argued the urgency to include the participation of vulnerable groups, such as indigenous communities, Afro-Mexicans groups, as well as the gender perspective, since no clear procedures have yet been established to raise awareness, reduce language barriers, or facilitate interaction with specific vulnerable groups.

Regarding to access to information, the Special Rapporteur on the human rights to safe drinking water and sanitation on his mission to Mexico declared that he obtained reports of deficient information from the authorities on water and sanitation and a lack of transparency in the information.

There were found 23 news items related to this subject (mainly on participation). The news stories evidenced some cases of demonstrations and citizen complaints demanding better sanitation services or solutions for economic losses due to the pollution problems, environmental demands from civil society, and complaints filed before the CNDH.

On the other hand, official information is the basis for accurate scientific studies about rights or any other aspects that need to be evaluated. There is some official information regarding the availability and quality of sanitation. However, there is a lack of information regarding physical accessibility and acceptability. Furthermore, information regarding equality and non-discrimination needs to be feasible to disaggregate (women, children, older adults, people affected with health conditions, or people with disabilities). 
Table 3. Cont.

Content of the HRS

9. Environmental protection
Summary of the Analysis

This was one of the most well-known components in the news coverage on sanitation, especially concerning the consequences of inadequate sanitation for ecosystems and natural resources. There were 90 news items, of which 69 were problems and 21 public responses. There were also found two official indicators.

According to information of 2019 , more than $50 \%$ of wastewater was discharged into water bodies without any treatment, generating contamination, loss of water quality, and damage to human health and ecosystems. Only $52.9 \%$ of the water bodies in the country were classified as having a "good" water quality status. Through the news items many significant contamination cases of natural water bodies in Mexico were identified. According to some news stories, environmental problems associated with sanitation in Mexico are due to pollution from residential or tourist real estate developments, pollution associated with corruption, damage to ecosystems and economic activities, and the violation of sanitation regulations.

General indicators on this regard are very helpful and easily identifiable, as well as many documents (from scientific articles to news items) have warned us about the environmental pollution problems in the country (especially regarding water pollution). However, water is not the only polluted element. For example, in urban areas sewerage overflows and spills contaminate streets and public places or can deteriorate the air quality through bad odors. For that reason, we suggest that more comprehensive indicators should be developed.

\subsection{Availability}

It implies that sanitation facilities (with associated services) are available to everyone and in sufficient numbers. Therefore, sufficient infrastructure is required, inside or in their household vicinity, and public places (schools, hospitals, workplaces, among others) [1]. In areas connected to public sewerage networks (usually urban areas), availability includes the entire infrastructure of the sanitation service chain (toilets, sewerage networks, and treatment plants). On the other hand, in rural areas, the sanitation infrastructure consists mainly of latrines, toilets, and septic tanks or biodigesters.

For this section, we found five indicators related to the topic and 58 news items. In Mexico, the total population in occupied housing units is 125.33 million, $98.1 \%$ of which have access to a toilet or latrine (93.7\% has toilets and $4.4 \%$ latrines). In comparison, $1.6 \%$ do not have any access [30]. Furthermore, sewerage coverage has remarkably increased in Mexico. In 1990, just over half of the population had sewerage and sanitation services, while in 2020, coverage was $93.8 \%$ [30,31].

On the other hand, $76.9 \%$ of the household population is connected to the public sewerage networks, and $16.9 \%$ have pits or septic tanks. However, $1.4 \%$ of the population (around 1.7 million people) discharge wastewater directly into ravines, cracks, rivers, lakes, and sea, and $4.5 \%$ (approximately 5.7 million people) do not have any wastewater drainage system [30].

In the last 15 years, there has been a $344 \%$ increase in the number of municipal wastewater treatment plants (WWTP) and a 319\% increase in treated wastewater flow. In 1996, there were 595 WWTP in operation with a treated flow of 33,745.4 L/s, while in 2019, there were 2642 municipal WWTP in operation, with a treated flow of 141,479 L/s [20]. Despite the significant progress, only about $65.7 \%$ of the municipal wastewater collected through sewerage systems is treated in Mexico [20], and if we considered municipal and industrial wastewater combined, the coverage wastewater treatment drops to $49.1 \%$ [21].

As a result, wastewater discharge into water bodies causes pollution problems. A documented case is in the state of Oaxaca, where the lack of sewerage and sanitation facilities forced a community to open a drain to discharge their wastewater into the Laguna Superior at the Isthmus of Tehuantepec, causing pollution problems [32]. Other damages arisen by the lack of sewerage networks and treatment plants include floods and sewage spills in some cities (as in Holbox, in the state of Quintana Roo [33,34]), causing public health difficulties, sewage odor problems, and economic damages to the population. 
Article 7 (VII) of the National Water Law (Ley de Aguas Nacionales: LAN) establishes that the construction and operation of water pollution prevention, control, and mitigation works, including WWTP, are of public interest [35]. Furthermore, Article 145 of the LAN Regulation establishes that the construction, operation, and maintenance of works and installations for the collection, transport, treatment, disposal, and discharge of wastewater must be subject to official Mexican standards [36]. In this regard, national news coverage presented some favorable public responses on sanitation issues in terms of availability, such as implementing sanitation works, projects, and investments. Some specific cases are the construction of collectors to stop pollution in the Magdalena River [37], the drainage works in Tlahuac [38] and the start-up of a WWTP in Mexico City [39], and the Eastern Drainage Tunnel (Túnel Emisor Oriente, TEO) in the metropolitan area of the Valley of Mexico [40]. Additionally, there has been construction of three treatment plants in León, Silao and Irapuato in the state of Guanajuato [41-43] and in Tlajomulco, Jalisco [44], the rehabilitation of the sewerage system in some communities of Oaxaca [45], as well as the joint work of sanitation infrastructure in the San Diego-Tijuana binational region [46].

However, there are still management problems for implementing sanitation works that hinder the exercise of sanitation as a human right. Within the management problems in Mexico, some national news items reported: unfinished works, lack of economic resources, poor sanitation infrastructure (e.g., $45 \%$ of primary schools lack sewerage connections [47]), the abandonment of sanitation infrastructure [48], the lack of congruence between the charges and the services provided, the lack of planning and prioritization, the lack of surveillance in compliance with sanitation regulations, and the lack of training for the construction of septic tanks in rural areas [49].

\subsection{Quality}

In terms of human rights, this includes quality of sanitation implies sanitation services, sewerage networks, and WWTP, working correctly, having adequate maintenance, and complying with the regulatory framework. It also includes the safe disposal of human excrements, and the avoidance of direct contact with waste [1].

Regarding official data, we found four pre-established indicators related to the component. In 2020, approximately 122.9 million people in Mexico had household toilet facilities ( $72.1 \%$ were flush toilets, $23.7 \%$ were pour-flush toilets, and $4.2 \%$ were non-flushing toilets/latrines) [30].

Under Article 3 (XIV) of the General Health Law (Ley General de Salud: LGS), basic sanitation is in the interest of public health in Mexico [50]. Approximately $88 \%$ of diarrheal illnesses are caused by a lack of sanitation, hygiene, and clean water [51]. Improved water supply reduces these diseases by between 6 and $21 \%$, while sanitation reduces them by $32 \%$ [52].

In Mexico, the sewerage and sanitation network increase has reduced water-borne diseases. The mortality rate from diarrheal diseases in children under five years old has been significantly reduced from 122.7 in 1990 to 7.3 in 2015 (per 100,000 children under five years old) [53], which means a decrease of $94 \%$. However, these diseases are still the second cause of death in this children population segment [54]. On the other hand, intestinal infectious diseases are among the top ten medical emergency conditions [55].

Quality was the first sanitation topic in the news coverage during the analysis period. There were found 110 news items on sanitation quality (79\% problems $/ 21 \%$ public responses). Some national news stories reported cases of spills, leaks, floods, and sewerage overflows due to the poor conditions of the sewerage systems. Between 2018 and 2020, some recurring cases of wastewater leaks and spills became visible in Torreón and Matamoros in the state of Coahuila [56,57], in Lerdo, Durango [58], and in Ciudad Madero, Tamaulipas [59], where the effects transcended other spheres such as public health and air quality.

Article 154 of the LAN Regulation establishes a systematic and permanent national water quality monitoring, including information and updates on WWTP inventory, the 
national inventory of wastewater discharges, and the quality of continental and marine waters [36].

In 2019, there were 3661 WWTP in the country; however, only $2642(72.2 \%)$ were in operation [20], meaning 1019 (27.8\%) of the WWTP were in disuse or abandoned. A news story reported that only $25 \%$ of the treatment plants operate adequately in the state of Oaxaca, mainly due to the lack of municipal budget and sewerage networks to transport wastewater to treatment plants [48].

Regarding wastewater discharges, Mexican legislation establishes some requirements. Under Article 135 of the LAN Regulation, individuals or legal entities that discharge wastewater must: (a) have a wastewater discharge permit issued by the National Water Commission (Comisión Nacional del Agua: CONAGUA); (b) treat the wastewater prior to its discharge to the receiving bodies, when necessary, to comply with the obligations established in the corresponding discharge permit; (c) pay-when appropriate-the federal right for the use of federal public properties as receiving bodies of wastewater discharges; and (d) install and maintain the gauging devices in good condition and the accesses for sampling that allow verifying the discharge volumes and the concentrations of the parameters foreseen in the discharge permits [35].

One indirect way to measure the proper functioning of the sanitation infrastructure is by monitoring the quality of the natural water bodies into which wastewater is discharged. NOM-001-SEMARNAT-1996 [60] establishes the maximum permissible limits of contaminants in wastewater discharges into national waters and assets. This regulation is still in force because the new regulation NOM-001-SEMARNAT-2021—which has already been approved in 2021 — has not been published to date in the Official Journal of the Federation [61].

On the other hand, NOM-002-SEMARNAT-1996 [62] establishes the maximum permissible limits of pollutants in wastewater discharges to urban or municipal sewerage systems. In the same way, NOM-014-CONAGUA-2003 [63] determines the requirements for the artificial recharge of aquifers with treated wastewater.

In 2020, Mexico's National Water Quality Measurement Network monitored 3493 surface water sites and 1068 groundwater sites. The results indicate that $63.7 \%$ of the surface water and groundwater sites did not comply with the established quality parameters [64].

The inadequate operation of the WWTP generates pollution on the Mexican coasts and water bodies. Several news items reported contamination due to wastewater discharges on beaches, lakes, and other natural water bodies, as well as the damage to ecosystems and economic activities [65-70].

Failures such as insufficient financial, human and technical resources, the lack of inspection and surveillance, the non-observance of regulations and laws, or the lack of incentives have been identified as the sources of sanitation quality problems [22]. However, national news coverage had identified some public responses aimed to solve the limitations for the full realization of the human right to sanitation (HRS) regarding its quality. Some of them are works and investment in sanitation and/or maintenance of facilities and networks (e.g., investment projects in the San Diego-Tijuana binational region, in Baja California [46], or investment in sanitation works in the State of Mexico and Oaxaca [45,71,72]), fines and sanctions, and technical training.

\subsection{Physical Accessibility}

It involves guaranteeing that the necessary means to realize this right are accessible to all people [73] in each household or within the immediate vicinity and in public spaces. It entails physical access to sanitation facilities at all times of day and night. The sanitation facilities and the path leading to them must ensure minimal risk to the physical security of users. It includes sanitation facilities be designed to enable people with special access needs and marginalized groups to access them physically [1]. Physical accessibility also involves access to sanitation for people living in remote places (rural areas). Few official data and only seven news items were found related to physical accessibility on sanitation. 
From the available data, we found that in Mexico, $5.9 \%$ of the population ( 7.56 million people) have some disability or limitation to moving (walk, go up or down). In Mexico, the primary causes of these disabilities or limitations are diseases $(36.9 \%)$ and advanced age (32.1\%) (which are also part of other vulnerable groups, such as chronically ill people and older adults) [74]. Therefore, if the sanitation services do not have the required physical accessibility, their right to sanitation could be violated for some people.

Furthermore, in Mexico, 8500 social assistance shelters serve vulnerable groups such as children, older adults, migrants, indigenous people, women victims of domestic violence, people experiencing homelessness, and people with health conditions or disabilities. Ninety-nine percent of these shelters are connected to sewerage networks. However, the availability of toilets with adaptations for people with disabilities is only $32.3 \%$ [75].

On the other hand, accessibility to sanitation differs in rural and urban areas. In rural areas, connection costs and physical inaccessibility to sewerage network connections make sanitation projects challenging to implement and also expensive for users, who in many cases are the ones that have to cover the costs [76]. According to the Report of the Special Rapporteur on the human rights to safe drinking water and sanitation on his mission to Mexico, access to water and sanitation is insufficient for rural communities with vulnerable populations. There is a limitation of access and availability of water and sanitation services that negatively affect women and girls, indigenous groups, and homeless people [23].

National news coverage presented some cases of communities in Mexico without access to sewerage networks [77], which led to the proliferation of latrines or septic tanks, many of which are poorly designed and lack hygienic conditions [49]. It is worth mentioning that there is the NOM-006-CONAGUA-1997 [78], which establishes the specifications and test methods of prefabricated septic tanks for the preliminary treatment of domestic wastewater, to ensure its reliability and contribute to the preservation of water resources and the environment. It establishes requirements such as the minimum recommended distances for the location of septic tanks.

Finally, in terms of accessibility, some national news stories also highlighted the two recommendations issued by the National Human Rights Commission (Comisión Nacional de Derechos Humanos: $\mathrm{CNDH}$ ) concerning the pollution of the Suchiapa River in the state of Chiapas (Recommendation 03/2020) [79], and the Atoyac River, in the state of Oaxaca (Recommendation 57/2020) [80]. In the first case, it has been argued that the municipalities have failed to comply with the criteria of availability and accessibility to basic public services of sewerage, treatment, and disposal of their wastewater [81]. In the second case, it has been claimed that there are few localities in Oaxaca with a municipal sewerage system service (only 11\%), and around 75,000 people do not have access to this public service [82].

\subsection{Affordability}

It means that access to sanitation facilities and services (including construction, maintenance, treatment, and disposal of fecal matter and wastewater) has to be economically accessible for all people, without limiting the possibility to acquire other essential services or enjoy other human rights [1]. It includes sewerage systems and on-site sanitation where sewerage usually is unavailable. The United Nations Development Program (UNDP) estimates that the cost of water and sanitation services should not exceed $3 \%$ of a household's income [83].

In Mexico, Article 23 (VII) of the General Law of Ecological Equilibrium and Environmental Protection (Ley General del Equilibrio Ecológico y la Protección al Ambiente: LGEEPA) establishes that water for urban uses must equitably incorporate its treatment costs, considering the impact on the quality of the resource and the quantity used [84]. On the other hand, Article 110 of the LAN [35] establishes that the operation, conservation, and maintenance of the hydraulic infrastructure will be at the expense of the users of the respective services.

The municipalities are responsible for the provision of water and sanitation services, and each one sets its rates under its state legislation, in accordance with Article 115 of 
the Mexican Constitution [85]. Thus, there are 2469 municipalities and approximately 2688 water and sanitation providers with different tariff systems. Some providers charge only flat fees, others charge flat fees plus extra rates after a certain volume, and many others charge tiered fees or apply separate fees for sewerage and/or wastewater treatment. There is a Mexican regulation on evaluating rates to recover costs for drinking water and sanitation services: NMX-AA-147-SCFI-2008 (DOF, 2008). However, in accordance with its content, this regulation is voluntary; thus, there are no uniform criteria for determining rates.

CONAGUA's National Water Information System compares water and sanitation tariffs for some cities in the country [86], based on a consumption of $30 \mathrm{~m}^{3}$ per month (Figure 6). According to this information, there are rates (combined water and sanitation) that range from over 60 pesos $/ \mathrm{m}^{3}$ (approximately 3 USD) to just 1.53 pesos $/ \mathrm{m}^{3}(0.07$ USD). Additionally, it can be observed that while the charge for sewerage and sanitation services can be disaggregated in some cities, it is included in a single charge in others.

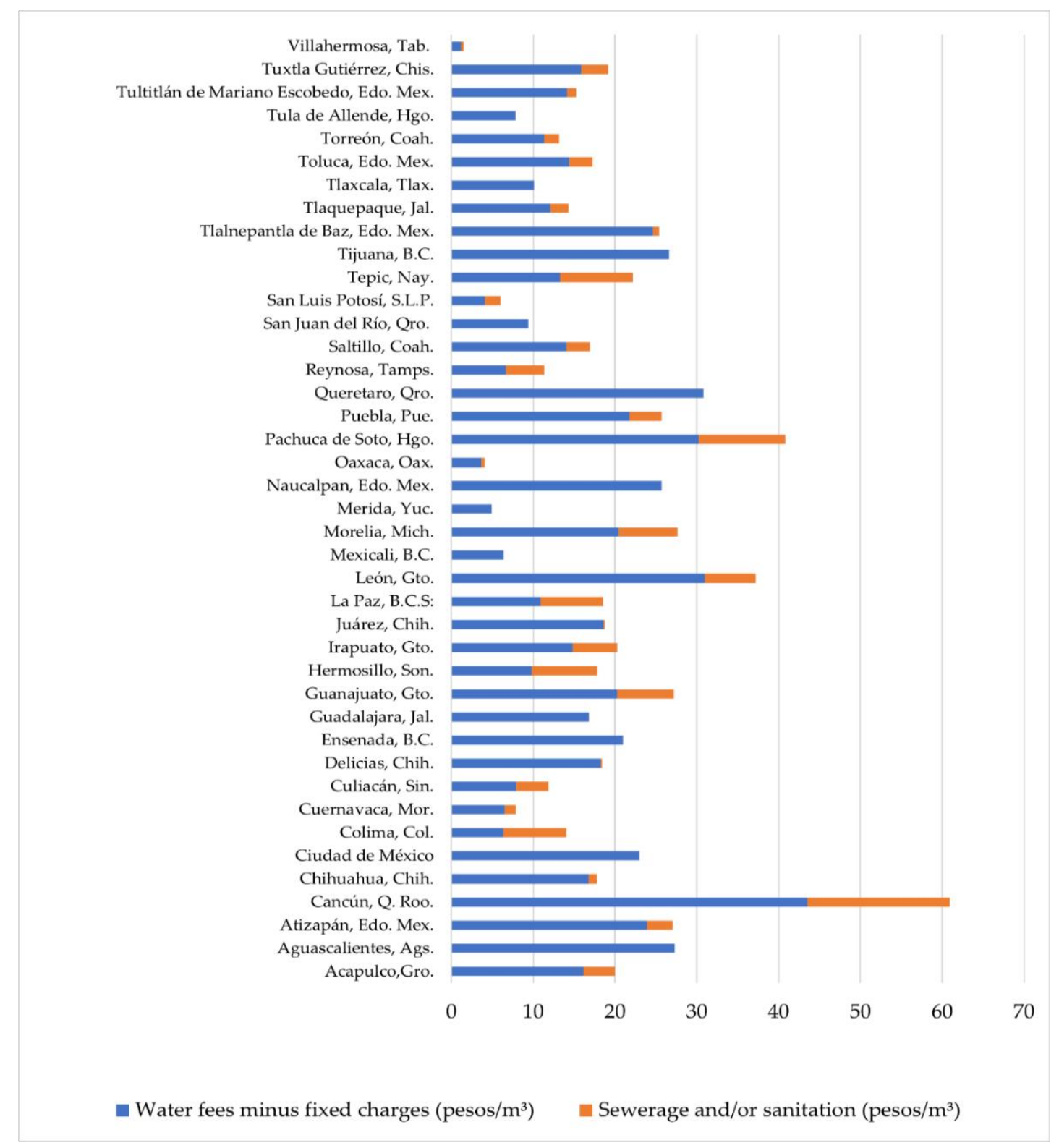

Figure 6. Comparison of rates of some cities in the country, based on a consumption of $30 \mathrm{~m}^{3}$ per month. 
Due to this variability, since no site includes all the information on the authorized rates in each municipality and some differences were found between various sources, it is difficult to make a correct estimate of the rates [73].

According to the World Health Organization (WHO), there are measures to benefit the low-income population in national policies and plans in Mexico. Some ways to ensure affordability are through subsidies, cost reduction for sanitation services, or in-kind contributions (e.g., labor) [1].

In Mexico, Article 282 of the Federal Rights Law (Ley Federal de Derechos: LFD) [87] establishes some exemptions to federal payments related to wastewater discharges. Thus, there are exempted for payment: populations of up to 10,000 and public or private water and sanitation providers for the wastewater discharges originating from them, as well as public or private non-profit entities that provide medical assistance, social services, or free education for the benefit of rural areas of up to 2500 people.

Likewise, Article 282-C of the LFD establishes that taxpayers with WWTP and those who in their production processes have implemented actions to improve the quality of their wastewater discharges, with equal or greater quality than that established in the Mexican regulation NOM-127-SSA1-1994 [88], may receive a 30\% discount on the payment.

Some news stories have documented the limitations of sanitation concerning affordability. Demonstrations have been registered, arguing high charges for water and sanitation services despite the deficiency of the services that generate wastewater leaks and overflows, as in Torreón, in the state of Coahuila [89]. Another news story in Pachuca, Hidalgo, reported that the lack of sewerage networks forces the population to use latrines or septic tanks with maintenance and emptying elevated costs, ranging from 10,000 pesos, equivalent to approximately 500 USD [49].

It must be considered that the selected technology can impact economic accessibility [1]. The costs of a WWTP (including installation, operation, and maintenance) are high, mainly due to the consumption of electrical energy, reagents, and replacement parts [90]. Despite this, it has been proven that public spending for social purposes has a favorable relationship with the level of coverage for both water and sanitation services. The public intervention has increased water and sanitation coverage in developing countries. On the contrary, since sanitation projects require initial solid investments and have low rates of return, it is not common for the private sector to finance them [76].

\subsection{Acceptability}

Sanitation solutions must be adapted to the social and cultural acceptability of the different regions (privacy, separate facilities for women and men in public places, hygiene practices and conditions, absence of sewerage odors)

In 2017, the Special Rapporteur on the human rights to safe drinking water and sanitation, on his mission to Mexico, declared that access to water and sanitation is not adequate for rural communities with a vulnerable population in the country. These communities have their traditions, culture, and practices, which must be considered and respected in public policies and programs [23]. This aspect is relevant for implementing public policies since sanitation is linked to the culture and privacy of people [1].

There is little official information on this topic. It is estimated that the exclusive or shared use of toilets in homes is an important element to consider for the acceptability and hygiene of sanitation services. About 123 million people have a household toilet facility, 91.78\% have a toilet for exclusive use at home, and $8.15 \%$ have a shared toilet (approximately 10 million people) [30].

On the other hand, 40 national news items were found related to the limitations of sanitation regarding acceptability (Figure 7). 


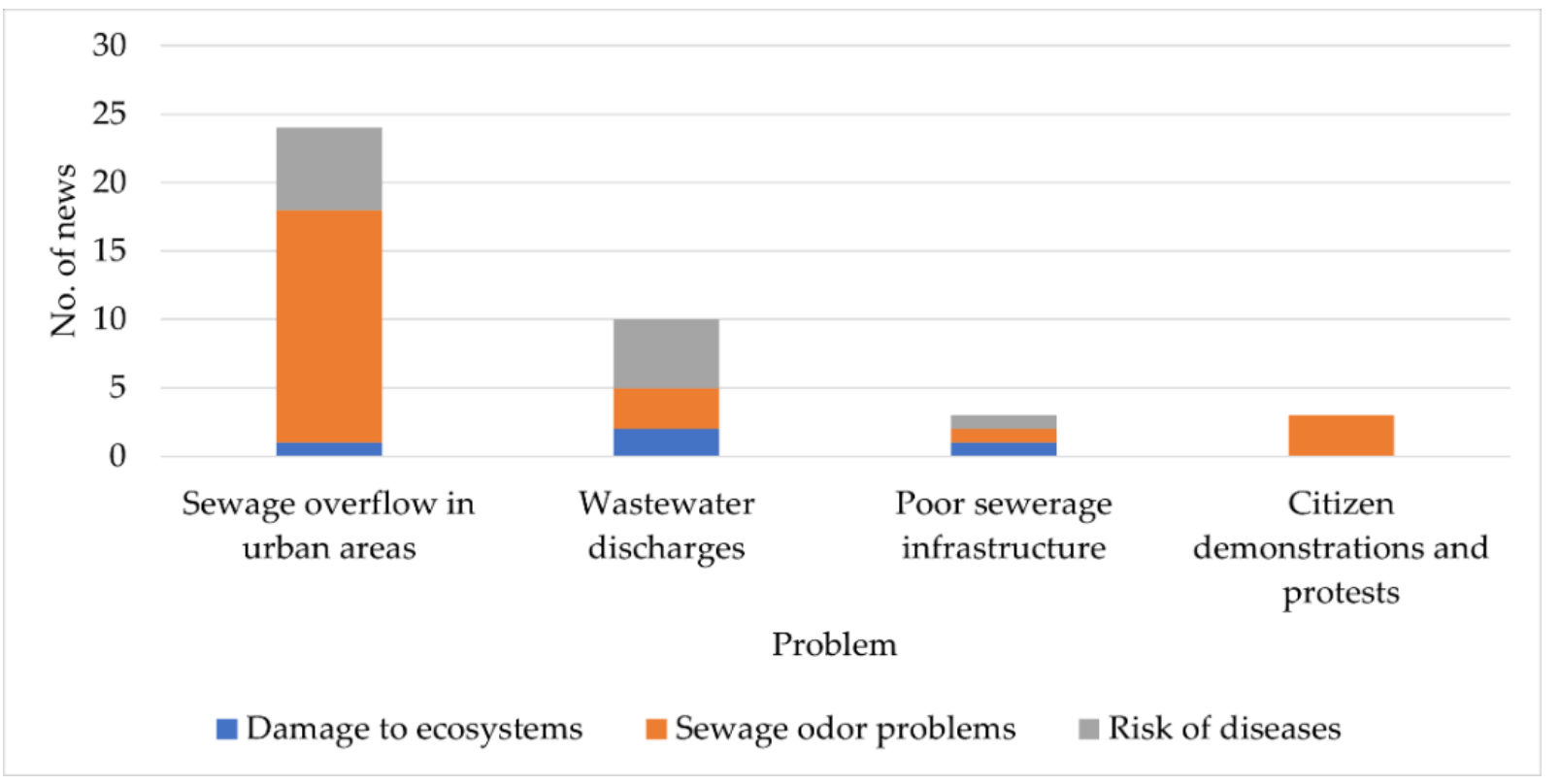

Figure 7. Problems associated with acceptable sanitation (news coverage analysis results).

One of the main aspects to consider sanitation as non-acceptable is the sewage odor generated due to the malfunction of the sewerage systems (overflows or leaks of wastewater mainly in urban areas, and discharges of untreated wastewater on beaches, rivers, lakes, or dams). It causes dirt in the streets and damage to public health and ecosystems. National news coverage has reported demonstrations, citizen protests, or social discontent due to the inadequate functioning of the sanitation systems and its consequences [56,58,91-94]. However, no information was found related to problems with privacy (for example, separated sanitation facilities for women and men in public places).

\subsection{Equality and Non-Discrimination}

Sanitation must be accessible, especially for the vulnerable and marginalized population (people living in poverty conditions, migrants, indigenous people, refugees, inmates and detainees, people with disabilities, women, children, older adults, people affected with health conditions, or people living in remote areas) [1,73]. The Mexican Constitution, in Article 1, states the obligation of all authorities to promote, respect, protect and guarantee human rights, and establishes the prohibition of discrimination. Additionally, Article 4, paragraph VI, indicates that every person has the right to the access, provision, and sanitation of water for personal and domestic consumption. The law must define the bases, supports, and modalities for equitable and sustainable access and use of water resources.

Despite this, in Mexico, the restricted access to drinking water and sanitation services is an obstacle to the country's economic growth and a source of inequality among the population [9]. More than 70\% of the country's households have problems associated with water rationing, low water pressure, and lack of sewerage network connections [95]. Poverty and social exclusion are components that restrict the realization of human rights, such as the HRS. Moreover, there is a two-way relationship between poverty and the environment since the low-income population suffers the damage of environmental pollution while this population is forced to impact natural resources to survive [96].

For this component, we found ten news items. A news story emphasized that the development plans for the marginalized areas of southern Mexico do not include basic water and sanitation works, which are necessary for the development and progress of the communities [97]. Likewise, some sanitation problems have been reported in marginalized areas, such as the poor basic sanitation services in some neighborhoods in Pachuca, in the 
state of Hidalgo [49], or the seismic events of September 2017, which caused the sanitation infrastructure to collapse in some communities of the state of Oaxaca [92].

The marginalized population is at a disadvantage in terms of the realization of their rights. Therefore, some special measures are required to facilitate the fulfillment of their rights and social well-being [96]. In this context, the LFD establishes some exceptions to the payment of the federal right for the use or exploitation of the federal public properties as receiving bodies of wastewater discharges to populations of up to 10,000 , non-profit entities that provide medical, social or free educational services for the benefit of rural populations of up to 2500, and domestic users in localities that lack sewerage systems [87]. Likewise, under Article 138 of the LAN Regulation, localities with less than 2500 people are exempt from complying with physicochemical and bacteriological characterization requirements [36].

Inequality and discrimination are due to economic, social, cultural, and even geographic factors [18]. A study conducted in 15 Latin American countries (including Mexico) determined that sanitation coverage between 1994 and 2014 in rural areas represented one of the most inequitable areas in Latin America [76]. It has been identified that the sanitation system is basic or nonexistent in some rural communities. There are also wastewater discharges in local streams, which are a source of supply for the population [23].

Between urban and rural areas, the challenges are different. While drainage and sewerage networks are generally available in urban areas, septic tank systems are employed for the disposal of wastewater in rural areas [90]. Therefore, the same techniques cannot be used for projects in remote locations and in urban areas. Other differences are funding or community participation [76].

We found two pre-established indicators related to equality and non-discrimination in sanitation. Concerning the availability of sewerage services and location of sewage disposal, there are about 35.15 million households in Mexico, of which, according to the national average: $78.1 \%$ are connected to the public sewerage network, $16.2 \%$ are connected to a septic tank or biodigester, $0.9 \%$ discharge their sewage in ravines or cracks, $0.4 \%$ discharge their drainage directly into rivers, lakes, or sea, and $4.3 \%$ do not have any drainage. However, there is a disparity between urban and rural areas. While in urban areas (localities of up to 2500 people), the sewerage network's coverage is $89.6 \%$, in rural areas (localities with less than 2500 people), it is only $32.1 \%$. Likewise, the rural population that does not have sewerage connections is $16.4 \%$, while the urban population is $1.2 \%$ [30]. On the other hand, discharges to septic tanks or biodigesters prevail in rural populations, being $47.9 \%$. In addition, rural communities register a higher percentage of discharges to ravines and cracks $(2.5 \%)$, and rivers, lakes, or sea (0.9\%) [30] (Figure 8 ).

Public policies on sanitation focus on water-based sanitation [98] since it is usually considered the most suitable option in the long term. However, fecal sludge management is generally unplanned, poorly regulated, and provided by informal service operants for on-site sanitation systems. Despite on-site sanitation being considered an interim solution for informal areas, it is used in many formal settlements [99].

On the other hand, the indigenous communities are within the main marginalized groups in Mexico. According to the National Institute of Indigenous Peoples, 87.5\% of the municipalities with indigenous populations observe a high or very high level of marginalization. In 2015, the total household population was 29.75 million, and $93.1 \%$ had access to public sewerage networks. However, the total household indigenous population was 2.79 million, of which $73.1 \%$ had access to those services [100].

News coverage involved some sanitation problems in indigenous communities. One is the case of the Chontales indigenous communities in the state of Tabasco, who have filed a complaint before the CNDH demanding to stop pollution of El Limón Lagoon [101]. Furthermore, some cases of rural indigenous communities in the state of Oaxaca lack access to sanitation and sewerage services [82].

There was no specific available information regarding other vulnerable groups. 


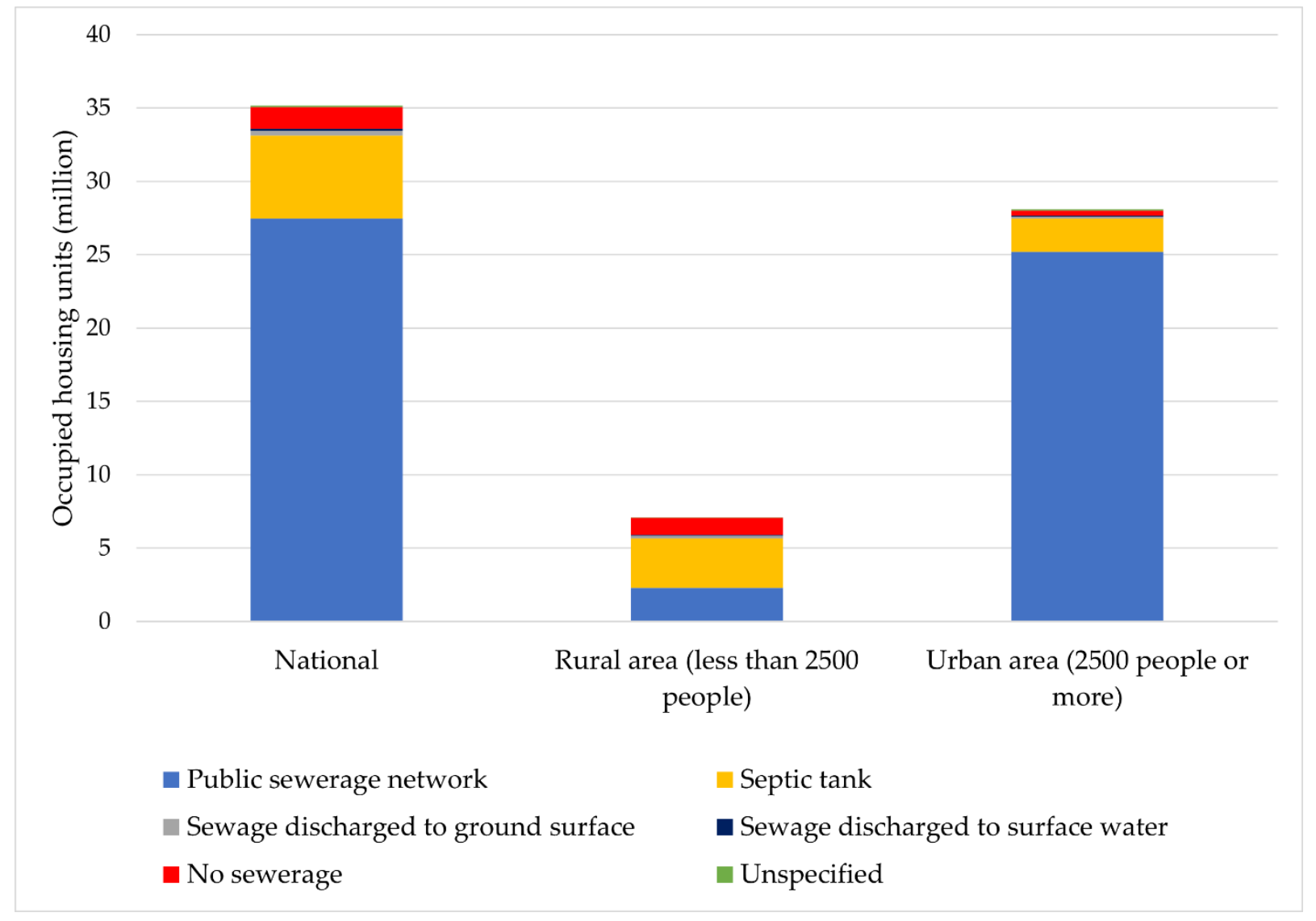

Figure 8. Availability of sewerage networks and place of discharge.

\subsection{Government Management and Inter-Institutional Coordination}

In Mexico, water and sanitation management is ruled by federal and state laws and regulations. However, it is implemented at the local level; thus, it is necessary to coordinate federal, state, and local actions. Article 4 of the Mexican Constitution, paragraph VI, mentions that the State must guarantee the human rights to water and sanitation, establishing the participation of the federal, state, and local governments, as well as the participation of citizens. In the same way, the law also considers coordination between different government agencies. Table 4 shows the municipalities, states, and some federal agencies' primary responsibilities on sanitation.

Despite the legislation that establishes concurrent competencies and responsibilities, sewerage systems and WWTP are under a scheme of fragmented responsibilities and without adequate coordination. This is one of the main problems in water and sanitation governance, and it generates problems over jurisdiction [22,23,102]. Joint decisions by many authorities make management a slow and challenging task (e.g., in the case of infrastructure development). Furthermore, delays and complications also arise due to differences in priorities and financial capabilities between authorities [102].

For this component, we only found one official indicator. According to the progress of indicator 6.5.1 of the Sustainable Development Goals (SDG) [103], in 2020, Mexican authorities were at a medium-low level in Integrated Water Resource Management (IWRM) (which includes water and sanitation). According to the results of this indicator, the authorities in Mexico have an explicit mandate to coordinate the implementation of IWRM and the capacity to guide the formulation of plans. However, there is still a lack of progress to conduct IWRM plans and their monitoring, evaluation, and adjustments. Likewise, there is some progress in sanitation in terms of inter-institutional coordination, such as the collaboration agreements established by CONAGUA to promote comprehensive sanitation of beaches and their international certification. Furthermore, in the cross-border 
region, CONAGUA works with the Agency for Environmental Protection of the United States in the Joint Investment Program for Drinking Water and Sanitation Infrastructure Projects [103].

Table 4. Primary responsibilities of the municipalities, states, and federation in sanitation, related to sanitation.

\section{Article/Law}

Art. 115/Mexican Constitution

Art. 88/LAN

Municipal Responsibilities

\section{Description}

It establishes that the municipalities are responsible for the services of drinking water, drainage, sewerage, treatment, and wastewater disposal.

It indicates that the municipalities are resposible for managing wastewater discharges to the sewerage systems of population centers.

It establishes that the municipalities are responsible to apply the legal provisions on the prevention and control of the contamination caused by the wastewater discharges of the population centers.

Art. 44/LAN and

It is the responsibility of the municipalities as well as the water and sanitation utilities, the wastewater treatment for urban public use prior to the discharge into receiving national water bodies.

It establishes that the CONAGUA ${ }^{\mathrm{d}}$ and the municipalities or water and sanitation utilities, together with the states, and the water and sanitation utilities, will establish the sites and measuring forms for water supply and the discharge of wastewater, and the compliance with quality regulations.

It establishes that when the wastewater discharges affect or may affect drinking water supply sources or public health, CONAGUA or the corresponding River Basin Organization will notify the authority and will dictate the denial or revocation of the corresponding permit, or the suspension of the water supply, as long as these anomalies are eliminated.

Concurrent

Responsibilities

(municipalities, states and federation)
Art. 89/LAN

Art. 119 BIS/LGEEPA

Art. 44/LAN
In terms of prevention and control of water pollution, the state governments and the municipalities are responsible for controlling wastewater discharges to sewerage systems, monitoring the corresponding official Mexican regulations, require those who generate wastewater discharges and do not comply with the regulation the installation of treatment systems, and register the discharges to their drainage and sewerage systems which will be integrated into the national registry of wastewater discharges.

The municipalities and the states are entitled to agree with the River Basin Organizations and CONAGUA on establishing regional systems of wastewater treatment discharges that have been discharged into a national water body.

The CONAGUA is responsible for studying the recommended payment fees for wastewater discharges, and promoting and supporting urban and rural public services for drinking water, sewerage, sanitation, recirculation, and reuse in coordination with the states and municipalities.

The CONAGUA is responsible to promote and provide state and municipal authorities with technical assistance to prepare studies and projects for drinking water, sewerage and sanitation works.

Federal Responsibility (CONAGUA and Ministry of Health)

The Federal Commission for the Protection of Sanitary Risks is responsible for proposing to the Ministry of Health the national policy against sanitary risks, including basic sanitation.

In their respective spheres of competence, the health, educational, and labor authorities will support and promote actions related to access to drinking water and sanitary means of eliminating excreta.

Art. 1343/Regulation of the LGS in matters of the sanitary control of activities, establishments, products, and services
It establishes that the Ministry of Health and the state governments will monitor compliance with the health regulations related to wastewater.

Notes: ${ }^{a}$ National Water Law; ${ }^{\mathrm{b}}$ General Law of Ecological Equilibrium and Environmental Protection; ${ }^{\mathrm{c}}$ Regulation of the National Water Law; ${ }^{\mathrm{d}}$ National Water Commission; ${ }^{\mathrm{e}}$ General Health Law. 
During this investigation, 51 national news items were associated with government management and inter-institutional coordination on sanitation matters (Figure 9).

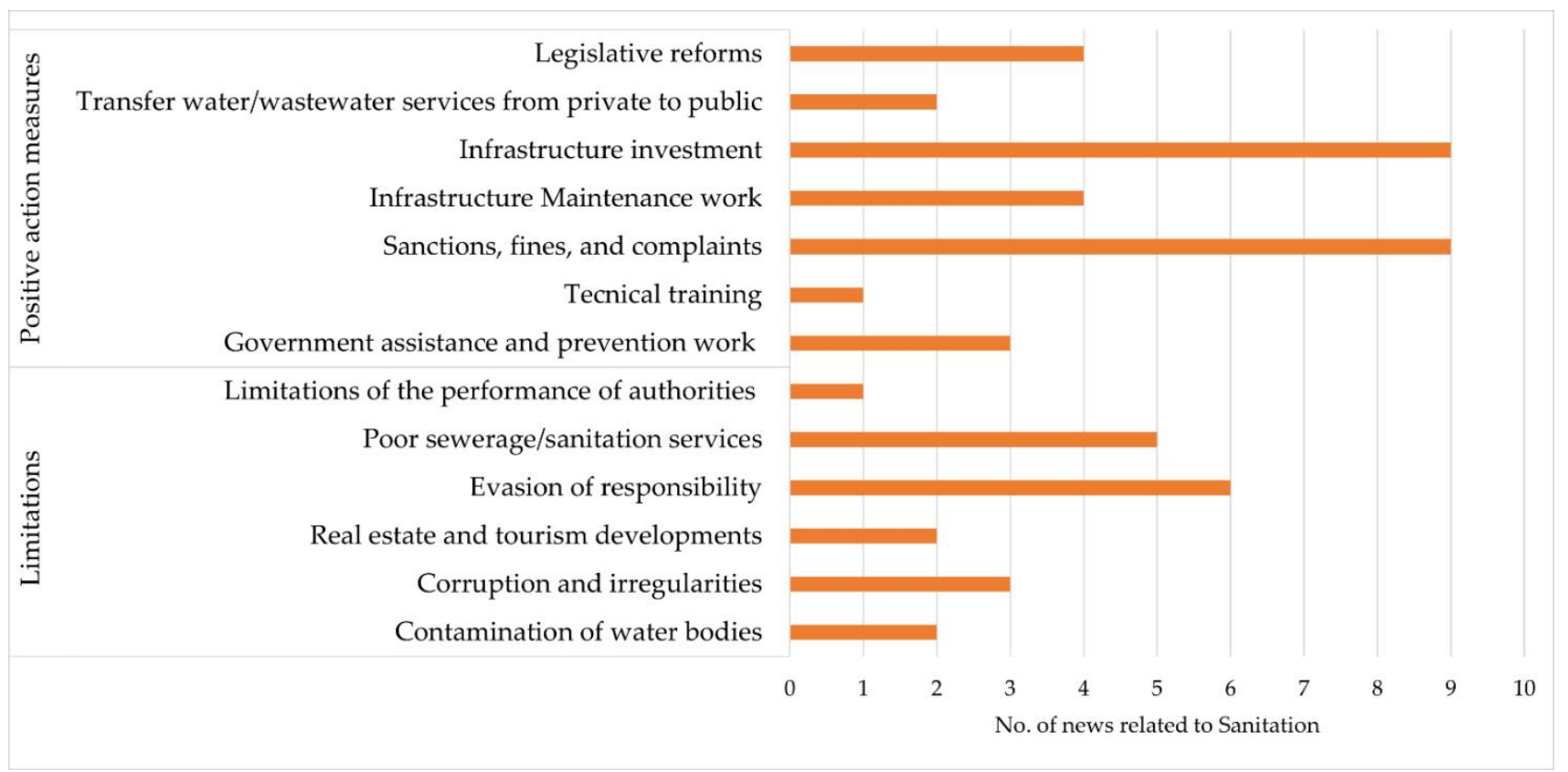

Figure 9. National news associated with sanitation management in Mexico.

Some of the news stories exhibited cases that limit the realization of the HRS, such as the lack of the authority's commitment to solving sanitation problems [92,104,105]. Other news items reported possible law violations on water and sanitation services (e.g., the irregularities investigated in Baja California [106] and Tamaulipas [107]), or the limitations on the actions of the institutions (since some institutions lack the legal authority to impose fines or penalties [108].

However, other news stories reported actions that enhance the exercise of the HRS. For example, legislation associated with sanitation, such as the reforms to the Law on the right to access, provision, and sanitation of water in Mexico City [109], the reform to Articles 88 Bis and 120 of the LAN to increase the amount on fines for those who pollute and exploit water without permission [110], or fines and sanctions, such as the case of dismissal of some authorities of the water and sanitation utility in Acapulco, in Guerrero [111]. Additional news stories include the provision to fine municipalities that do not invest resources to treat their wastewater in the state of Tamaulipas [112], the closure of a WWTP due to contamination in Tlaxcala [113], and the transfer of water and sanitation utilities from private to public management, as in León, Guanajuato [114], and in the Tampico-Madero region, in Tamaulipas [115].

\subsection{Access to Information and Public Participation}

All people must have equal access to information on water, sanitation, and the environment. States must have adequate, precise, updated, and detailed information on sanitation coverage in the country. The information must be complete and transparent [116]. Likewise, each person has the right to participate in the decision-making process that affects their rights to water and sanitation. The States must guarantee the participation of the people in the planning, construction, maintenance, and supervision of the sanitation services [16].

For this component, there were two official indicators. According to the 2020 results of indicator 6.5.1 of the SDG in Mexico [103], some mechanisms have been established to facilitate participation in the public sphere in terms of sanitation (such as the 42 clean beach committees that promote water management in coastal areas). Likewise, in the private sector, the LAN recognizes the Water Advisory Council as an autonomous advisory body 
formed of individuals from the private and social sectors sensitive to water problems and their management. However, it has been argued the urgency to include the participation of vulnerable groups, such as indigenous communities, Afro-Mexicans groups, as well as the gender perspective, since no clear procedures have yet been established to raise awareness, reduce language barriers, or facilitate interaction with specific vulnerable groups. The Special Rapporteur on the human rights to safe drinking water and sanitation on his mission to Mexico, declared that he obtained reports of deficient information from the authorities on water and sanitation, as well as a lack of transparency in the information [23].

On the other hand, 23 news stories were found on participation and the right to information concerning sanitation. Related to participation, news coverage emphasized (1) citizen demonstrations in demand of better water and sanitation services (the blockades due to dysfunctional sewerage networks in Torreón, Coahuila [89,94,117-119], and in Ciudad Madero, Tamaulipas [91,120], and the demonstrations by fishers due to the high level of contamination that caused damage to their productive activity in the Gulf of Tehuantepec [121]); (2) the environmental demands of civil society (the demands of environmental groups in the Tula region, in Hidalgo [122-124], as well as in the Santiago River and other regions of Jalisco [125,126], and for wastewater treatment projects [127]); (3) attention of the government to complaints about sanitation problems [128-130]; and (4) complaints filed before the CNDH.

Concerning access to information, there is the National Water Information System (Sistema Nacional de Información del Agua: SINA), some annual official publications on drinking water and sanitation by CONAGUA, as well as the General Law of Transparency and Access to Public Information [103]. However, there are still some limitations. News coverage presented the case of pollution of the beaches of Acapulco, Guerrero, in which the authorities made allegations of false information regarding the origin of the pollution and assured that contamination was due to stormwater discharges and not sewage $[93,104,105]$. News coverage also reported that the National Institute of Transparency, Access to Information and Protection of Personal Data, ordered CONAGUA to report on the discharge of pollutants in Lerma River and Lake Chapala [131].

\subsection{Environmental Protection}

Pollution is one of the main problems of bodies of water, rivers, lakes, groundwater, and coastal areas. It comes mainly from urban wastewater and chemical products from agriculture and industry [6].

Everyone has the right to access adequate and safe water and sanitation services [116]. However, a sustainable urban water (and sanitation) system should not have adverse environmental effects, while providing the required services and protecting human health [132]. The lack of access to sanitation for some people affects the entire community or other communities that will suffer the consequences of the generated pollution. People have the right not to be negatively impacted by the mismanagement of wastewater by others, and the States must protect these people [98].

For this component, we found two official indicators. In 2019, only $49.1 \%$ of municipal and industrial wastewater generated in Mexico was adequately treated [21]. It means that more than $50 \%$ was discharged into water bodies without any treatment. Considering that one liter of wastewater can contaminate approximately $8 \mathrm{~L}$ of freshwater [133], the amount of untreated wastewater can have a considerable multiplier effect [6]. Only $52.9 \%$ of the water bodies in the country were classified as having a "good" water quality status [21].

The environmental component is one of the most recurrent topics in news coverage on sanitation in Mexico, especially regarding the consequences that inadequate sanitation causes for ecosystems and natural resources. There were found 90 national news items that associated sanitation with socio-environmental issues. Some significant cases of pollution of water bodies in Mexico were the contamination in the Tula River in Hidalgo [122,124,134,135], on the Papaloapan River in Veracruz [136], on some beaches of Baja California [65,66], Guerrero [67], the Pánuco River and the Chairel and Carpintero 
lagoons in Tamaulipas [69,137-139]. Likewise, news coverage reported some pollution damage to ecosystems, such as damage to the reefs of Cozumel, Quintana Roo [140,141], in the Arroyo Moreno Mangrove in Veracruz [142], the death of fish due to contamination in La Estanzuela dam in Hidalgo [70] and Lake Chapultepec in Mexico City [68], and damage to oyster production due to wastewater discharges in the Pánuco River, in the state of Tamaulipas [69].

From this news coverage analysis, it was possible to determine that some limitations of the environmental component associated with sanitation in Mexico are (1) contamination by residential or tourist real estate developments, such as the case of the Bacalar Lagoon, where its development has been accompanied by contamination due to poor management of sewerage and septic tanks [143], (2) cases of pollution associated with possible law violations on water and sanitation services $[106,144]$, (3) damage caused by pollution to ecosystems and productive activities (for example in the case of fishing activity in the Gulf of Tehuantepec, which has been affected by the pollution produced by untreated wastewater discharged by homes [121]); and (4) the non-compliance with regulations that generate pollution [145].

Moreover, there were some public responses to the problem of contamination due to inadequate sanitation. These actions include (1) the closure of companies, hotels, or WWTP for pollution problems [113,146-148], environmental demands of civil society (the demands to decrease pollution in the Tula region in Hidalgo [122-124,149], (3) the cases filed before the CNDH and the Inter American Commission of Human Rights (IACHR) $[81,82,150,151]$ ), and (4) sanitation works and projects to prevent the contamination (e.g., the works that plan to avoid wastewater discharges in the Tula-Tepeji region [135], and the sanitation of the Molola River in Tepic, Nayarit [152]).

\section{Conclusions}

Sanitation as a human right entails looking at other elements not considered from the traditional sanitation approach. In addition to the shared vision of sanitation, as the availability of infrastructure and its proper functioning for wastewater treatment and disposal, it includes social components such as the access to sanitation facilities for vulnerable groups; cultural, economic, and environmental components; as well as the necessary institutional and management arrangements, aspects of equality and non-discrimination, and the access to information and public participation.

However, the lack of official data of some human right to sanitation (HRS) components makes the studies challenging. For this reason, other resources are necessary. The analysis of news coverage played an important role in this research since it made it possible to consider other problems and the society-HRS dynamics that may not be feasible to identify within the official data.

This research helped us to identify the main sanitation problems in Mexico from a comprehensive perspective. Although there has been considerable progress in sanitation in Mexico, there are still significant challenges to realizing this human right. One of the most visible problems of sanitation is the pollution of water; however, a comprehensive sanitation solution is needed (that means considering from the access to sanitation facilities to the safe disposal or reuse of waste). There are problems related to the sanitation and sewerage infrastructure, such as the lack of maintenance works (availability and quality), obstacles associated with the physical and economic accessibility of these services for the vulnerable population, inequalities between urban and rural areas, lack of information of some HRS criteria (physical availability, acceptability and equality and non-discrimination), and government management and inter-institutional coordination problems.

This investigation also led us to identify variables for possible indicators for future research to evaluate sanitation as a human right according to the specific Mexican context. Finally, this study contributes to inter and multidisciplinary research on the relationship between quality of life, development, and the environment. It represents an effort to capture the complexity of sanitation in Mexico as a human right and its current situation 
and, at the same time, a path for future studies of the HRS assessment considering a comprehensive perspective.

Author Contributions: Conceptualization, V.G.-S.; methodology, V.G.-S., M.V.-C. and M.C.A.-G.; validation, V.G.-S., M.V.-C. and L.W.D.; formal analysis, V.G.-S., M.A.-H. and M.C.P.-T.; investigation, V.G.-S. and M.C.A.-G.; writing-original draft preparation, V.G.-S.; review and editing, V.G.-S., M.V.-C., M.C.A.-G., L.W.D., M.A.-H. and M.C.P.-T.; project administration, V.G.-S. and M.V.-C. All authors have read and agreed to the published version of the manuscript.

Funding: This research was funded by Universidad Autónoma de Baja California, project: Participatory Groundwater Quality Monitoring in Arid-Coastal Zones in Baja California. Funding call No. XXII.

Institutional Review Board Statement: Not applicable.

Informed Consent Statement: Not applicable.

Data Availability Statement: The data presented in this study are available on request from the corresponding author.

Acknowledgments: We thank the Mexican Council for Science and Technology (CONACYT) scholarship and the support from the Universidad Autónoma de Baja California (UABC).

Conflicts of Interest: The authors declare no conflict of interest.

\section{Appendix A}

Table A1. News coverage on sanitation problems in México by HRS component.

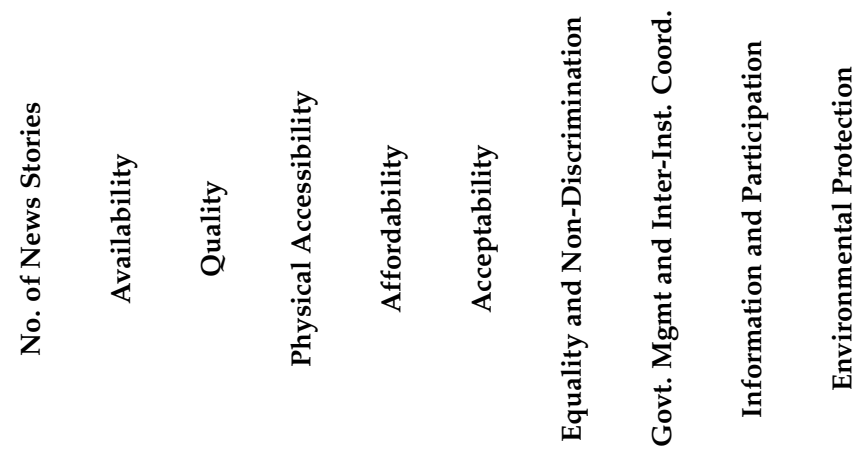

91

$3 \quad 1$

$\begin{array}{lll}1 & 1 & 3\end{array}$

- Lax criteria for contamination in Mexico and lack of supervision. 4

- $\quad$ Lack of wastewater treatment in Mexico/Poor sanitation services. 5

Baja California 4

- Closure of beaches in Ensenada due to wastewater pollution. 1

- Wastewater pollution in the Tijuana-San Diego region. 2

- Investigation of companies in Tijuana for polluting discharges. 1

- $\quad$ Outbreaks of wastewater from sewers and drains, overflows in rainy seasons, mainly caused by sewerage networks in poor condition, in many city areas.

- Sewage spill in the treatment plant caused the death of dozens of fish in the Lake Mayor of Chapultepec. 
Table A1. Cont.

Problems (by State)

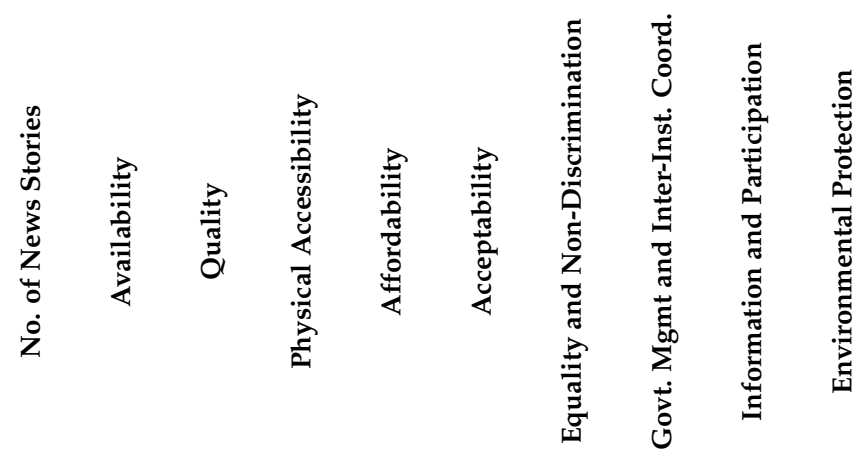

\section{Coahuila}

- $\quad$ Pollution in the Aguanaval River.

- Leaks, odors problems, and outbreaks of wastewater through sewers and drains, in several neighborhoods in the cities of Torreón and Matamoros, which cause sources of infection to the population.

- $\quad$ Protests, demonstrations, and/or blockades demanding solutions to sanitation problems in the city of Torreón.

\section{Durango}

Outbreak of wastewater in the streets adjacent to the hospital in the city of Gómez Palacio.

- Wastewater leaks that generate problem odors and sources of infection in various neighborhoods in the city of Lerdo.

Discharges of wastewater in the De la Villa River cause damage to 1 health and tourism.

\section{Estado de México}

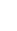

Natural borders receive discharges from neighbors who use them as natural canals for their sewage.

Wastewater contamination in El Capulín dam.

- Floods due to rains and infrastructure failures.

- Overflow of the Coatepec River, San Agustín Canal, Angulo dam, due to rain and lack of maintenance.

- Proliferation of irregular wastewater discharges from human settlements and real estate developments.

- Entrance restricted in Guadalupe Lake due to discharges of municipal wastewater.

Guanajuato

- Wastewater discharges in De la Olla dam.

- $\quad$ Leaks, odor problems, and sewage spills in the city of León. 1

- $\quad$ Death of WWTP workers in León.

1

\section{Guerrero}

17

3

3

- Wastewater contamination of beaches in Acapulco.

- Municipal government argues that pollution problems are due to rainwater and not wastewater. 
Table A1. Cont.

Problems (by State)

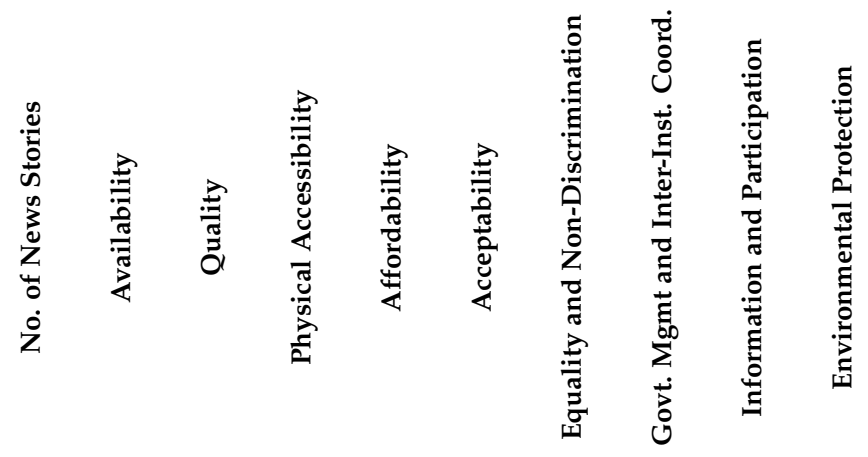

Hidalgo

- Wastewater pollution from Mexico City on the Tula River.

- Wastewater contamination in the La Estanzuela dam causes the death of fish.

- Wastewater canal overflow.

- Lack of basic services in the municipality of Pachuca.

Jalisco

$12 \quad 1 \quad 10$

- Wastewater in the Cajititlán Lagoon.

1

- Open-air wastewater canal generates pollution.

- Drinking water with fecal residues.

- Pollution of the Santiago River.

- Pollution due to the collapse of collectors.

4

- Pollution in Lagunas region.

1

Michoacán 1

- $\quad$ Pollution of Lake Patzcuaro.

$$
1
$$

Morelos

- Denounce of lack of sewerage services.

Nayarit

1

- Health alert for contamination of Sayulita beach

$\begin{array}{lllll}1 & 1 & 1 & 1 & 1\end{array}$

Nuevo León

\section{1}

- Contamination of the La Silla River due to wastewater leaks.

Oaxaca

1

1

1

1

- Wastewater pollution of the Gulf of Tehuantepec causes economic damage to the fishing sector.

- Poor infrastructure, lack of maintenance, and abandonment of wastewater treatment plants.

- $\quad$ Suspended fishing and closed permits due to wastewater contamination in the lagoon caused by some communities discharges into the Los Perros River.

- Juchitán residents decided to open a drain due to the lack of sewerage networks and pour their sewage into it, which flows into the lagoon. 
Table A1. Cont.

Problems (by State)

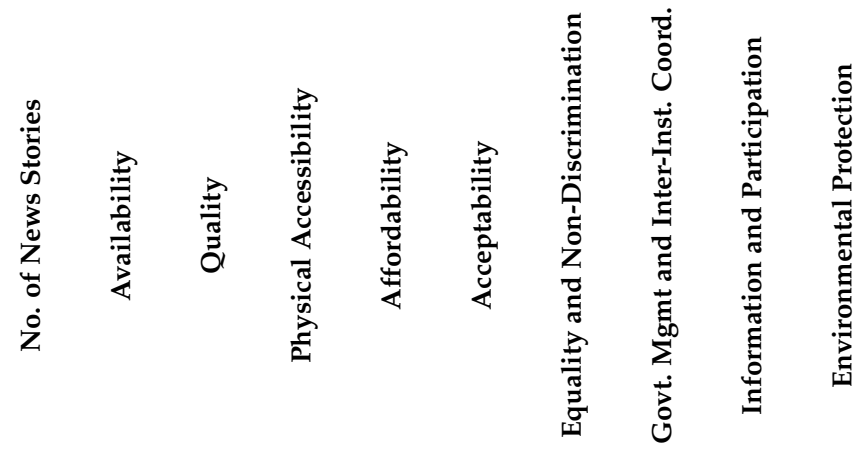

Puebla

- Wastewater contamination in the Atoyac River, Puebla.

5
2

- Drainage overflow in Tlacuilotepec road despite work recently 1 completed two years ago.

- $\quad$ Lack of treatment plants in municipalities.

1

- Unfinished projects. The wastewater treatment plant project in 1 Coapan is abandoned.

\begin{tabular}{llllc} 
Querétaro & $\mathbf{1}$ & & 1 \\
- Pollution in the Querétaro River. & 1 & & 1 \\
\hline Quintana Roo & $\mathbf{8}$ & 5 & 2 & 1 \\
- Hotel closure due to damage to ecosystems. & 1 & & & 2
\end{tabular}

- Pollution in Bacalar Lagoon due to the proliferation of real estate developments that discharge wastewater untreated and poorly $\quad 1$ managed septic tanks.

- $\quad$ Poor and unhealthy sewerage in Holbox. 4

- Hoteliers pour sewage into the reefs of Cozumel. 2

Tabasco

- $\quad$ Chontales take a complaint to $\mathrm{CNDH}$ for contamination of the El Limón lagoon.

\section{Tamaulipas}

$2 \quad 2$

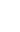

- Wastewater contamination in the El Carpintero Lagoon and the Pánuco River.

- Urgent to give priority to wastewater treatment projects.

- Drainage spill causes health problems (dermatitis and stomach problems) in the Villas de Altamira subdivision, of the La Pedrera community.

- $\quad$ Sewage spills in streets in Tampico and Madero.

- $\quad$ Pandemic increased sewage discharges to lagoons and rivers in $\quad 1$ Tamaulipas.

- $\quad$ Problems with oyster production due to the wastewater discharges into the Pánuco River.

- Protests and blockades due to repeated sewage outbreaks in Ciudad Madero homes. 
Table A1. Cont.

Problems (by State)

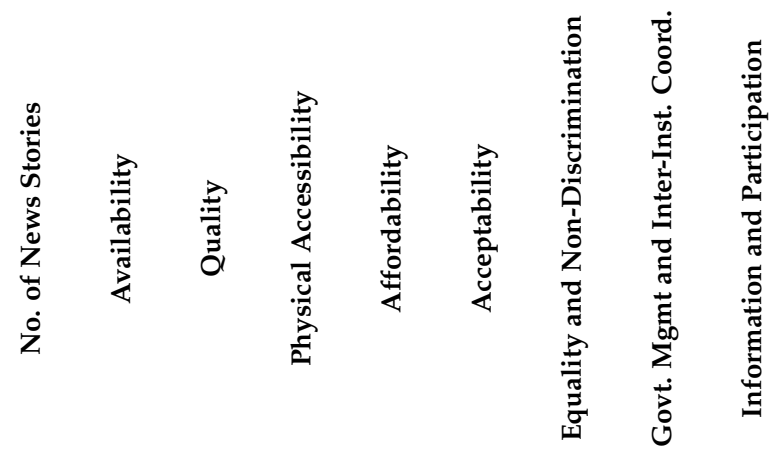

- $\quad$ Pollution in the Papaloapan River.

- Urbanism threatens the mangrove swamp of Boca del Río.

- Contamination (fecal matter) in cenotes.

Table A2. News coverage on sanitation public responses by HRS component.

Public Responses (by State)

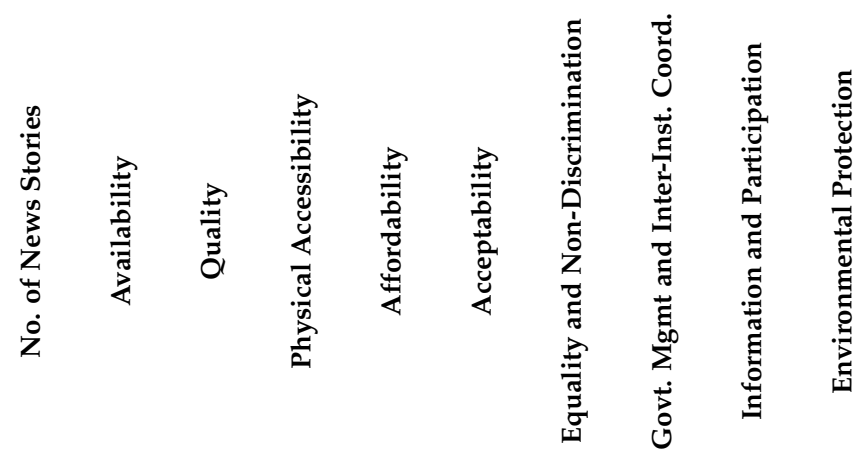

\section{Nacional}

2

- Penalties increase for those who pollute and exploit water without permission.

- $\quad$ Progress on the law of public service price adjustments for 2021. 1

Baja California

- Binational project and rehabilitation of wastewater treatment infrastructure in the Tijuana-San Diego region

\section{CDMX}

- $\quad$ Legislative reforms of the Sacmex law.

1

2

- Political acts.

$5 \quad 3 \quad 4$

5 
Table A2. Cont.

Public Responses (by State)

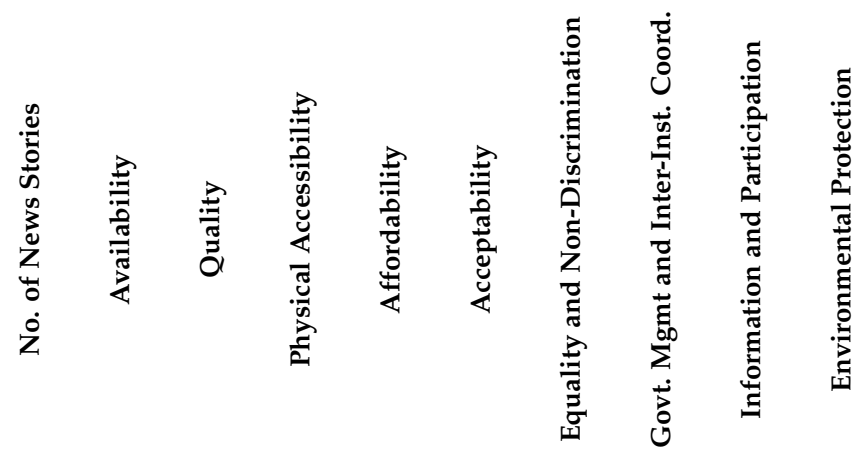

\begin{tabular}{llcc}
\hline Chiapas & 2 & 1 & 1 \\
- CNDH recommendations for river contamination. & 2 & & 2 \\
\hline Coahuila & 2 & 2 & 1 \\
- Infrastructure maintenance. & 1 & & \\
- Political acts. & 1 & & \\
\hline
\end{tabular}

Edo. Méx.

6

- $\quad$ Repairs of sewerage networks and sanitation work in Ecatepec. 4

- Agreement to deal with wastewater discharge to the lagoon in 1 Toluca.

- $\quad$ Cleaning of rivers in Texcoco

1

Guanajuato

- Construction of treatment plants in Irapuato, León, and Silao.

\begin{tabular}{llll}
1 & \\
1 & & & \\
\hline & 3 & 1 & 1
\end{tabular}

3

- Recovery of private water and sanitation services in León. 1

Guerrero 3

- Presidential commitment to address the wastewater problem.

1

- $\quad$ CNDH recommendations for river contamination. 1

- Dismissal of directors.

1

Hidalgo

- Complaint in European countries for the contamination problem in Hidalgo.

- $\quad$ Sanitation works.

1

Jalisco

- Precautionary measures of the IACHR.

Precautionary measures of the IACHR. 1

- Closure of companies due to damage to the Santiago River. 1

- Demand to judicial authorities. 1

- $\quad$ Recovery of the Santiago River. 1

- INAI orders the National Water Commission (CONAGUA) to 1 report information about the discharge of pollutants.

- $\quad$ New wastewater treatment plant.

- $\quad$ Proposition to suspend industrial water discharges.

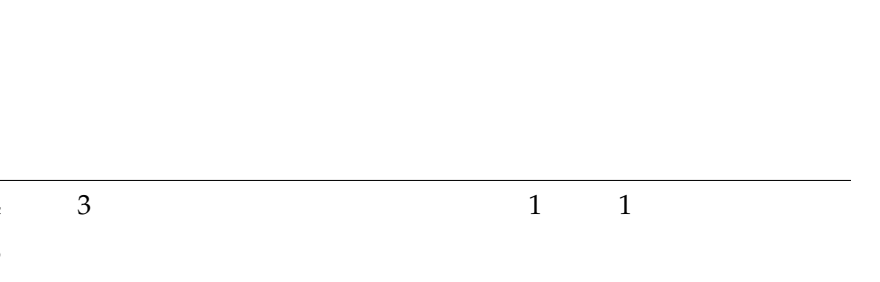


Table A2. Cont.

Public Responses (by State)

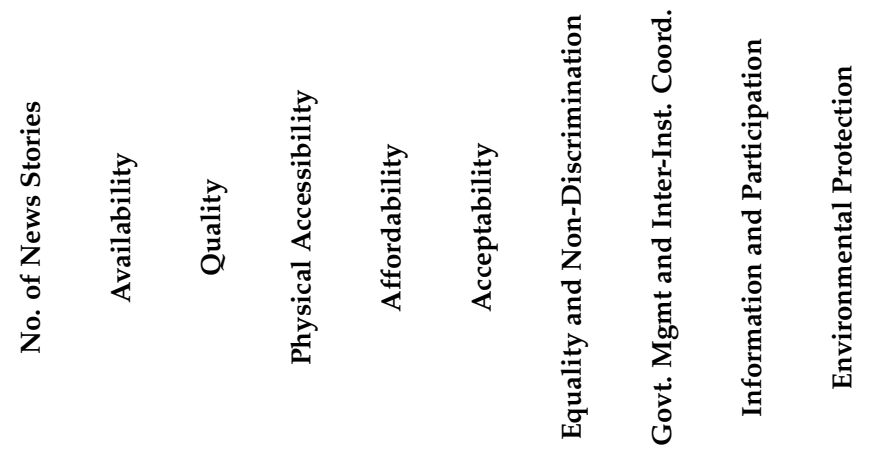

\begin{tabular}{|c|c|c|c|c|c|c|}
\hline \multirow{2}{*}{$\begin{array}{l}\text { Morelos } \\
\text { - } \quad \text { Sanitation works. }\end{array}$} & \multirow{2}{*}{$\begin{array}{l}1 \\
1\end{array}$} & \multicolumn{5}{|l|}{1} \\
\hline & & & & & & \\
\hline Nayarit & 1 & & 1 & & 1 & 1 \\
\hline - Cleanup of the Molola River. & 1 & & & & & \\
\hline Nuevo León & 1 & & & & 1 & 1 \\
\hline $\begin{array}{l}\text { - Congress demands sanctions against Water and Drainage of } \\
\text { Monterrey for river ecocide. }\end{array}$ & 1 & & & & & \\
\hline Oaxaca & 4 & 3 & 2 & 1 & 1 & 1 \\
\hline - $\quad \mathrm{CNDH}$ recommendations for river contamination. & 1 & & & & & \\
\hline - Sanitation works in Juchitán. & 3 & & & & & \\
\hline Puebla & 3 & 1 & 1 & & 1 & \\
\hline - $\quad$ Sanitation works investment. & 2 & & & & & \\
\hline - Hydraulic project stopped due to possible contamination. & 1 & & & & & \\
\hline Quintana Roo & 2 & & 1 & & 2 & 2 \\
\hline - Hotel closure. & 1 & & & & & \\
\hline $\begin{array}{l}\text { Lawsuit against CONAGUA and the Drinking Water and } \\
\text { Sewerage Commission (CAPA) in Quintana Roo for the } \\
\text { non-compliance with works and wastewater discharges. }\end{array}$ & 1 & & & & & \\
\hline Tamaulipas & 6 & 2 & 1 & & 4 & \\
\hline - $\quad$ Sanitation works. & 2 & & & & & \\
\hline $\begin{array}{l}\text { - Government of Tamaulipas takes control of } 3 \text { wastewater } \\
\text { treatment plants. }\end{array}$ & 1 & & & & & \\
\hline $\begin{array}{l}\text { Fines will be applied to municipalities that do not provide } \\
\text { resources to treat wastewater. }\end{array}$ & 1 & & & & & \\
\hline - $\quad$ Sanitation works investments. & 1 & & & & & \\
\hline $\begin{array}{l}\text { - Criminal complaint about a case of water treatment plants in } \\
\text { Tamaulipas. }\end{array}$ & 1 & & & & & \\
\hline Tlaxcala & 2 & & 2 & & 1 & 2 \\
\hline - $\quad$ Profepa closures wastewater treatment plant in Tlaxcala. & 2 & & & & & \\
\hline
\end{tabular}




\section{References}

1. United Nations. Report of the Independent Expert on the Issue of Human Rights Obligations Related to Access to Safe Drinking Water and Sanitation, Catarina de Albuquerque (A/HRC/12/24); UNGA: New York, NY, USA, 2009.

2. United Nations. The Human Right to Water and Sanitation (A/RES/64/292); UNGA: New York, NY, USA, 2010.

3. United Nations. Statement on the Right to Sanitation (E/C.12/2010/1); ECOSOC: Geneva, Switzerland, 2010.

4. Diario Oficial de la Federación (DOF). Decreto Por el Que se Declara Reformado el Párrafo Quinto y se Adiciona un Párrafo Sexto Recorriéndose en su Orden los Subsecuentes, al Artículo 4o. de la Constitución Política de los Estados Unidos Mexicanos (Decree by Which the Fifth Paragraph Is Declared Amended and a Sixth Paragraph Is Added, Going through the Subsequent Ones in Their Order, to Article 4. of the Political Constitution of the United Mexican). 2012. Available online: http://dof.gob.mx/nota_ detalle.php?codigo=5232952\&fecha=08/02/2012\&print=true (accessed on 20 January 2021).

5. World Heath Organization [WHO]. Guidelines on Sanitation and Health; WHO: Geneva, Switzerland, 2019; ISBN 978-92-4-151470-5.

6. UNAM-CNDH. Estudio Sobre la Proteccion de Ríos, Lagos y Acuiferos Desde la Perspectiva de los Derechos Humanos (Study on the Protection of Rivers, Lakes and Aquifers from the Perspective of Human Rights); UNAM-CNDH: Ciudad de México, Mexico, 2018.

7. World Heath Organization (WHO). Who Water, Sanitation and Hygiene. Strategy 2018-2025; WHO: Geneva, Switzerland, 2018.

8. United Nations World Water Assessment Programme (WWAP). The United Nations World Water Development Report 2017. Wastewater: The Untapped Resource; UNESCO: Paris, France, 2017; ISBN 978-92-3100201-4.

9. Comisión Nacional del Agua (CONAGUA). Diagnóstico Para el Reforzamiento y Ampliación del Programa Directo de Agua Limpia CONAGUA 2014 (Diagnosis for the Reinforcement and Expansion of the Direct Clean Water Program CONAGUA 2014); CONAGUA: Ciudad de México, Mexico, 2014.

10. United Nations. Sustainable Development Goal 6, Synthesis Report on Water and Sanitation 2018; UN: New York, NY, USA, 2018.

11. United Nations. The 2030 Agenda and the Sustainable Development Goals. An Opportunity for Latin America and the Caribbean; UN: Santiago, Chile, 2018.

12. Iribarnegaray, M.A.; Gatto D’Anda, M.L.; Rodriguez-Alvarez, M.S.; Hernández, M.E.; Brannstrom, C.; Seghezzo, L. From Indicators to Policies: Open Sustainability Assessment in the Water and Sanitation Sector. Sustainability 2015, 7, 14537-14557. [CrossRef]

13. Hashemi, S. Sanitation Sustainability Index: A Pilot Approach to Develop a Community-Based Indicator for Evaluating Sustainability of Sanitation Systems. Sustainability 2020, 12, 6937. [CrossRef]

14. United Nations. Frequently Asked Questions on a Human Rights-Based Approach to Development Cooperation; OHCHR: New York, NY, USA; Geneva, Switzerland, 2006.

15. UN-OHCHR. Los Derechos Humanos y la Agenda 2030 Para el Desarrollo Sostenible (The Human Rights and the 2030 Agenda for Sustainable Development). Available online: https://ohchr.org/SP/Issues/SDGS/pages/the2030agenda.aspx (accessed on 13 February 2022).

16. United Nations. Human Rights and Access to Safe Drinking Water and Sanitation (A/HRC/RES/12/8); UNGA: New York, NY, USA, 2009.

17. Obani, P. Strengthening the Human Right to Sanitation as an Instrument for Inclusive Development; CRC Press/Balkema: Leiden, The Netherlands, 2018; ISBN 978-113-861-848-0.

18. Winkler, I.T. The human right to sanitation. Univ. Pa. J. Int. Law 2016, 37, 1331-1406.

19. Obani, P.; Gupta, J.J. Human right to sanitation in the legal and non-legal literature: The need for greater synergy. Wiley Interdiscip. Rev. Water 2016, 3, 678-691. [CrossRef]

20. Comisión Nacional del Agua (CONAGUA). Inventario Nacional de Plantas Municipales de Potabilización y de Tratamiento de Aguas Residuales en Operación (National Inventory of Municipal Water Treatment and Wastewater Treatment Plants in Operation); CONAGUA: Ciudad de México, Mexico, 2019.

21. Instituto Nacional de Estadística Geografía e Informática (INEGI). Sistema de Información de los Objetivos de Desarrollo Sostenible en México 2021 (System of Information of the Sustainable Development Goals in Mexico 2021). Available online: https:/ /agenda2030.mx/\#/home (accessed on 15 December 2021).

22. Ortiz, G.A.; Donath, E. Instrumentos Legislativos y Económicos de Política Pública: Hacia el Logro de la Gestión Integrada del Agua en México (Legislative and Economic Instruments of Public Policy: Towards the Achievement of Integrated Water Management in Mexico); IMTA: Jiutepec, Mexico, 2012; ISBN 978-607-7563-51-8.

23. United Nations. Report of the Special Rapporteur on the Human Rights to Safe Drinking Water and Sanitation on His Mission to Mexico (A/HRC/36/45/Add.2); UNGA: New York, NY, USA, 2017.

24. Grant, A. Doing Excellent Social Research with Documents; Routledge: New York, NY, USA, 2009; ISBN 978-113-803-865-3.

25. Ahmed, J.U. Documentary Research Method: New Dimensions. Indus J. Manag. Soc. Sci. 2010, 4, 1-14.

26. Hernandez-Sampieri, R.; Fernandez-Collado, C.; Baptista-Lucio, P. Metodología de la Investigación (Research methodology), 5th ed.; Mc Graw Hill: Ciudad de México, Mexico, 2010; ISBN 978-607-15-0291-9.

27. Organization of American States (OAS). Progress Indicators for Measuring Rights under the Protocol of San Salvador; OAS: Washington, DC, USA, 2015.

28. Rivera Salas, P.E.; Curro Lau, M.G. Promoción de la calidad de vida a través del periodismo responsable digital (Promoting quality of life through responsible digital journalism). Index Comun. 2021, 11, 187-217. [CrossRef] 
29. Sánchez Vazquez, M.J.; Blas Lahitte, H.; Tujague, M.P. El Análisis Descriptivo Como Recurso Necesario en Ciencias Sociales y Humanas (The Descriptive Analysis as a necessary resource in Social and Human Sciences). Fundam. Humanid. 2010, 11, 103-116.

30. Instituto Nacional de Estadística Geografía e Informática (INEGI). Censo de Población y Vivienda 2020 México (Population and Housing Census 2020 Mexico). Available online: https://inegi.org.mx/programas/ccpv/2020/ (accessed on 30 May 2021).

31. Comisión Nacional del Agua (CONAGUA). Atlas del Agua en México 2018 (Atlas of Water in Mexico 2018); CONAGUA: Ciudad de Mexico, Mexico, 2018.

32. Aguas Negras Contaminan Laguna Superior en el Istmo de Tehuantepec (Black Waters Pollute Laguna Superior on the Isthmus of Tehuantepec). El Universal, 7 July 2019. Available online: https:/ /www.eluniversal.com.mx/estados/contaminan-con-aguasnegras-35-mil-hectares-de-la-laguna-superior-en-oaxaca (accessed on 19 February 2021).

33. Varillas, A. Drenaje Insalubre en Holbox (Unhealthy Drainage in Holbox). El Universal, 9 February 2018. Available online: https:// www.eluniversal.com.mx/estados/denuncian-crisis-por-drenaje-sanitario-en-calles-de-holbox (accessed on 19 February 2021).

34. Varillas, A. Se Desbordan Aguas Residuales de Hotel a Hotel en Holbox (Sewage Overflows from Hotel to Hotel in Holbox). El Universal, 4 February 2020. Available online: https:/ /www.eluniversal.com.mx/estados/se-desbordan-aguas-residuales-dehotel-hotel-en-holbox (accessed on 19 February 2021).

35. Diario Ofiicial de la Federación (DOF). Ley de Aguas Nacionales (National Waters Law). 1992. Available online: http:/ / www. diputados.gob.mx/LeyesBiblio/pdf/16_060120.pdf (accessed on 2 January 2021).

36. Diario Oficial de la Federación (DOF). Reglamento de la Ley de Aguas Nacionales (Regulation of the National Water Law). 1994. Available online: http://www.diputados.gob.mx/LeyesBiblio/regley/Reg_LAN_250814.pdf (accessed on 2 February 2021).

37. Suárez, G. Concluyen Trabajos de Saneamiento del Río Magdalena (Sanitation Works of the Magdalena River Conclude). El Universal, 2 February 2018. Available online: https://www.eluniversal.com.mx/metropoli/cdmx/concluyen-trabajos-desaneamiento-del-rio-magdalena (accessed on 19 February 2021).

38. Ayala, C. Gobierno de CDMX Presenta Avances en Obras de Drenaje en Tláhuac (Mexico City's Government Presents Progress in Drainage Works in Tláhuac). El Economista, 18 October 2020. Available online: https://www.eleconomista.com.mx/estados / Gobierno-de-CDMX-presenta-avances-en-obras-de-drenaje-en-Tlahuac-20201018-0035.html\%0A (accessed on 19 February 2021).

39. Buscan Sacar Provecho a Aguas Residuales en CDMX (They Seek to Take Advantage of Wastewater in Mexico City). Excélsior, 22 October 2019. Available online: https:/ / www.excelsior.com.mx/comunidad/buscan-sacar-provecho-a-aguas-residuales-encdmx/1343316 (accessed on 22 February 2021).

40. Fernández, E. Con Avance de 98\%, Preparan Apertura de Drenaje Profundo (Deep Drain Opening Is Prepared with $98 \%$ Advance). El Universal, 13 June 2019. Available online: https: / / www.eluniversal.com.mx/metropoli/con-avance-de-98-preparan-aperturade-drenaje-profundo (accessed on 13 February 2021).

41. En León, Sapal Construirá Más Plantas de Tratamiento de Agua (Sapal Will Build More Water Treatment Plants in Leon). Milenio, 17 April 2020. Available online: https://www.milenio.com/politica/comunidad/leon-sapal-construira-plantas-tratamiento-agua (accessed on 26 February 2021).

42. Tendrá Silao Planta Para Tratar Aguas Residuales (Silao Will Have a Plant to Treat Wastewater). Milenio, 28 September 2020. Available online: https://www.milenio.com/politica/comunidad/construiran-planta-tratamiento-aguas-residuales-silao (accessed on 23 February 2021).

43. Construyen Planta de Tratamiento en Irapuato Para Saneamiento de Agua (They Build a Treatment Plant in Irapuato for Water Sanitation). Milenio, 10 February 2021. Available online: https://www.milenio.com/politica/comunidad/construyen-plantatratamiento-irapuato-saneamiento-agua (accessed on 26 February 2021).

44. Ramírez, M. Nueva Planta Tratadora de Aguas Residuales Comenzará Con al Menos 5 mil Casas en Colonia La Noria (New Wastewater Treatment Plant Will Start with at Least 5000 Houses). Milenio, 20 January 2021. Available online: https://www. milenio.com/politica/comunidad/tlajomulco-planta-tratadora-aguas-5-mil-casas (accessed on 23 February 2021).

45. Manzo, D. Juchitán Tendrá Nuevo Drenaje Sanitario; Estiman 70 mil Beneficiados (Juchitán Will Have a New Sanitary Drainage; They Estimate 70 Thousand Beneficiaries). La Jornada, 20 January 2020. Available online: https://www.jornada.com.mx/ ultimas/estados/2020/01/20/juchitan-tendra-nuevo-drenaje-sanitario-estiman-70-mil-beneficiados-9746.html\%0A (accessed on 12 February 2021).

46. Martínez, G. Proyecto Binacional Fomentará la Región de Tijuana y San Diego (Binational Project Will Promote the Tijuana and San Diego Region). El Economista, 27 February 2018. Available online: https:/ / www.eleconomista.com.mx/estados/Proyectobinacional-fomentara-region-de-Tijuana-y-San-Diego-20180227-0008.html (accessed on 19 February 2021).

47. Instituto Nacional Para la Evaluación de la Educación (INEE). La Educación Obligatoria en México. Informe 2019 (Compulsory Education in Mexico. 2019 Report); INEE: Ciudad de México, Mexico, 2019.

48. Zavala, J.C. En el Olvido, 95 Plantas Para Aguas Residuales (In Oblivion, 95 Wastewater Plants). El Universal, 27 January 2019. Available online: https:/ / www.eluniversal.com.mx/estados/en-el-olvido-95-plantas-para-aguas-residuales-en-oaxaca (accessed on 13 February 2021).

49. Mota, D. Fosas Sépticas. Foco de Infección que se Niega a Desaparecer (Septic Tanks. Source of Infection That Refuses to Go Away). El Universal, 19 November 2018. Available online: https:/ /www.eluniversal.com.mx/estados/fosas-septicas-foco-deinfeccion-que-se-niega-desaparecer (accessed on 19 February 2021).

50. Diario Oficial de la Federación (DOF). Ley General de Salud (General Law of Health). 1984. Available online: http://www. diputados.gob.mx/LeyesBiblio/ref/lgs.htm (accessed on 10 January 2021). 
51. Comisión Nacional del Agua (CONAGUA). Estadísticas del Agua en México 2018 (Water Statistics in Mexico 2018); CONAGUA: Ciudad de México, Mexico, 2018.

52. World Heath Organization (WHO). Water, Sanitation and Hygiene Links to Health. Facts and Figures—*Updated November 2004. Available online: https:/ / www.who.int/water_sanitation_health/WSHFact-Spanish.pdf?ua=1 (accessed on 10 January 2021).

53. Comisión Nacional del Agua (CONAGUA). Numeragua México 2018; CONAGUA: Ciudad de México, Mexico, 2018.

54. Secretaría de Salud. Panorama Epidemiológico y Estadístico de la Mortalidad por Causas Sujetas a Vigilancia Epidemiológica en México 2017 (Epidemiological and Statistical Overview of Mortality from Causes Subject to Epidemiological Surveillance in Mexico 2017). Available online: https:/ / www.gob.mx/salud/documentos / panorama-epidemiologico-y-estadistico-de-lamortalidad-por-causas-sujetas-a-vigilancia-epidemiologica-en-mexico-2017 (accessed on 3 March 2021).

55. Secretaría de Salud. Breviario de Estadísticas de Salud en México, 2018 (Breviary of Health Statistics in Mexico, 2018); Secretaría de Salud: Ciudad de México, Mexico, 2018.

56. Castillo, K. Denuncian Brote de Aguas Negras en Colonia Morelos de Torreón (Outbreak of Sewage in Neighborhood in Torreón). Milenio, 27 July 2020. Available online: https://www.milenio.com/estados/torreon-denuncian-brote-aguas-negras-coloniamorelos (accessed on 25 February 2021).

57. Aguilar, C. En La Laguna, Familias Viven Entre Arroyos de Aguas Negras (In La Laguna, Families Live Among Black Water Streams). Milenio, 21 September 2020. Available online: https://www.milenio.com/estados/laguna-familias-viven-arroyosaguas-negras (accessed on 24 February 2021).

58. Rábago, I. Vecinos de Villa Jardín Con Problemas por Brote de Aguas Negras (Villa Jardín Neihbors with Prolems Due to Sewage Utbreak). Milenio, 5 June 2020. Available online: https:/ / www.milenio.com/estados/durango-lerdo-vecinos-sufren-brote-aguasnegras (accessed on 25 February 2021).

59. Meza, A. Brotan Aguas Negras de Baños tras Lluvias en sur de Tamaulipas (Sewage Flows from Bathrooms after Rains in Southern Tamaulipas). Milenio, 26 June 2020. Available online: https:/ / www.milenio.com/politica/comunidad/tamaulipascolonias-sufren-afectaciones-lluvias-aguas-negras (accessed on 25 February 2021).

60. Diario Oficial de la Federación (DOF). NOM-001-SEMARNAT-1996 Que Establece los Límites Máximos Permisibles de Contaminantes en las Descargas de Aguas Residuales en Aguas y Bienes Nacionales (NOM-001-SEMARNAT-1996 Which Establishes the Maximum Permissible Limits of Pollutants in Wastewater Discharges into National Waters). 1996. Available online: http:/ / dof.gob.mx/nota_detalle.php?codigo=4863829\&fecha=06/01/1997 (accessed on 10 January 2021).

61. Ramírez-Salinas, N. Actualización de la NOM-001-SEMARNAT-2021 Hacia una Mejor Calidad en los Cuerpos de Agua (Update of NOM-001-SEMARNAT-2021 towards Better Quality in Water Bodies). Available online: https://www.youtube.com/watch?v= 7I4VUy59NjI (accessed on 10 September 2021).

62. Diario Oficial de la Federación (DOF). NOM-002-SEMARNAT-1996 Que Establece los Límites Máximos Permisibles de Contaminantes en las Descargas de Aguas Residuales a los Sistemas de Alcantarillado Urbano o Municipal (NOM-002-SEMARNAT-1996 Which Establishes the Maximum Permissible Limits of Pollutants in Wastewater Discharges to Urban or Municipal Sewerage Systems). 1998. Available online: http:/ / dof.gob.mx/nota_detalle.php?codigo=4881304\&fecha=03/06/1998 (accessed on 10 January 2021).

63. Diario Oficial de la Federación (DOF). NOM-014-CONAGUA-2003 Requisitos Para la Recarga Artificial de Acuíferos con Agua Residudal Tratada (NOM-014-CONAGUA-2003 (Requirements for the Artificial Recharge of Aquifers with Treated Wastewater). 2003. Available online: http:/ / dof.gob.mx/nota_detalle.php?codigo=5105753\&fecha=18/08/2009 (accessed on 10 January 2021).

64. Comisión Nacional del Agua (CONAGUA). Calidad del Agua en México (Water Quality in Mexico). Available online: https: //www.gob.mx/conagua/articulos/calidad-del-agua (accessed on 20 December 2021).

65. Cierran Playas en Ensenada por Contaminación (Beaches Closed in Ensenada Due to Contamination) Milenio, 7 January 2020. Available online: https://www.milenio.com/estados/cierran-playas-en-ensenada-por-contaminacion (accessed on 19 February 2021).

66. Martínez, G. Cierran Playas de Tijuana y San Diego por Contaminación (Tijuana and San Diego Beaches Closed Due to Contamination). El Universal, 12 January 2018. Available online: https:/ / www.eluniversal.com.mx/estados/cierran-playas-detijuana-y-san-diego-por-contaminacion (accessed on 19 February 2021).

67. Trujillo, T. Reportan Nueva Descarga de Aguas Negras en Playas de Acapulco (New Discharge of Sewage on Acapulco Beaches). Milenio, 16 September 2020. Available online: https:/ / www.milenio.com/estados/vuelven-reportar-descarga-aguas-negrasplayas-acapulco (accessed on 23 February 2021).

68. López, J. Falla en Planta Mata a Más de 100 Peces en Lago de Chapultepec (Plant Failure Kills More Than 100 Fish in Chapultepec Lake). Excélsior, 21 October 2020. Available online: https:/ /www.excelsior.com.mx/comunidad/falla-en-planta-mata-a-mas-de100-peces-en-lago-de-chapultepec/1412516 (accessed on 19 February 2021).

69. Montoya, J.R. Reportan Muerte de Peces en Presa La Estanzuela, en Hidalgo (Death of Fish Reported in La Estanzuela Dam). La Jornada, 22 September 2021. Available online: https:/ / www.jornada.com.mx/ultimas/estados/2020/09/22/reportan-muerte-depeces-en-presa-la-estanzuela-en-hidalgo-7489.html\%0A (accessed on 15 February 2021).

70. Gómez, C. Peligra Producción de Ostión por Descarga de Aguas Negras (Oyster Production is in Danger due to Sewage Discharge). Milenio, 26 September 2019. Available online: https:/ / www.milenio.com/politica/comunidad/rio-panuco-descargas-aguasnegras-amenazan-produccion-ostion (accessed on 25 February 2021). 
71. Fernández, E. Ecatepec va a Reparar Drenaje Tras Inundación (Ecatepec is Making Sewerage Working). El Universal, 30 September 19. Available online: https://www.eluniversal.com.mx/metropoli/ecatepec-va-reparar-drenaje-tras-inundacion (accessed on 20 February 2021).

72. Velasco, Ángeles. Repara Ecatepec 170 Socavones; Reemplaza Drenaje con 50 Años de Existencia (Ecatepec Repairs 170 Sinkholes; Replaces 50 Years Old Drainage Networks). Excélsior, 7 August 2020. Available online: https://www.excelsior. com.mx/comunidad/repara-ecatepec-170-socavones-reemplaza-drenaje-con-50-anos-de-existencia/1398622 (accessed on 10 January 2021).

73. CNDH-IMTA. Formulación y Calibración de Indicadores Para Generar un Diagnóstico de la Situación de Cumplimiento de los Derechos Humanos, Respecto de Acceso Humano al Agua y a un Medio Ambiente Sano en Materia de Agua en México (Formulation and Calibration of Indicators to Generate a Diagnosis of the Situation of Compliance with Human Rights, Regarding Human Access to Water and a Healthy Environment in Terms of Water in Mexico); CNDH-IMTA: Ciudad de México, Mexico, 2019.

74. Instituto Nacional de Estadística Geografía e Informática (INEGI). Censo de Población y Vivienda 2020. Tabulados Predefinidos. Cuestionario Ampliado. Discapacidad (Population and Housing Census 2020. Predefined Tables. Expanded Questionnaire. Disability). Available online: https:/ / www.inegi.org.mx/programas/ccpv/2020/\#Tabulados (accessed on 23 May 2021).

75. Instituto Nacional de Estadística Geografía e Informática (INEGI). Censo de Población y Vivienda 2020. Tabulados Predefinidos. Características de Alojamientos de Asistencia Social (Population and Housing Census 2020. Predefined Tables. Social Housing Characteristics). Available online: https:/ / www.inegi.org.mx/programas/ccpv/2020/\#Tabulados (accessed on 23 May 2021).

76. Pinilla-Rodríguez, D.E.; Torres-Sánchez, Y.A. Gasto Público Social, el Acceso al Agua Potable y el Saneamiento de las Poblaciones Rurales en América Latina (Public Social Spending, Access to Drinking Water and Sanitation of Rural Populations in Latin America). Probl Desarro 2019, 50, 55-82. [CrossRef]

77. Morelos, R. Vecinos Acusan Cobros 'Excesivos' de Predial en Tlayacapan, Morelos (Neighbors Accuse 'Excessive' Property Charges in Tlayacapan). La Jornada, 11 February 2021. Available online: https://www.jornada.com.mx/notas/2021/02/11 /estados/vecinos-acusan-cobros-excesivos-de-predial-en-tlayacapan-morelos/ (accessed on 25 February 2021).

78. Diario Oficial de la Federación (DOF). NOM-006-CONAGUA-1997. Fosas Sépticas Prefabricadas-Especificaciones y Métodos de Prueba (NOM-006-CONAGUA-1997. Prefabricated Septic Tanks-Specifications and Test Methods) 1999. Available online: https: / / www.dof.gob.mx/nota_detalle.php?codigo=4942502\&fecha=29/01/1999 (accessed on 1 January 2021).

79. Comisión Nacional de Derechos Humanos (CNDH). Recomendación No. 03/2020 (Recommendation No. 03/2020). Available online: https:/ / www.cndh.org.mx/documento/recomendacion-32020 (accessed on 12 June 2021).

80. Comisión Nacional de Derechos Humanos (CNDH). (CNDH), Recomendación No. 57/2020 (Recommendation No. 57/2020). Available online: https:/ / www.cndh.org.mx/documento/recomendacion-572020 (accessed on 12 June 2021).

81. Ortiz, A. CNDH Emite Recomendación por Contaminación de Río Suchiapa (Mexico's National Human Rights Commission issues Recommendation for Pollution of Suchiapa River). El Universal, 19 March 2021. Available online: https:/ / www.eluniversal com.mx/nacion/sociedad/cndh-emite-recomendacion-por-contaminacion-de-rio-suchiapa (accessed on 15 February 2021).

82. Mejía, F. CNDH Pide Detener Contaminación de Heces Fecales del río Atoyac en Oaxaca (Mexico's National Human Rights Commission Calls to Stop Contamination of Feces from the Atoyac River in Oaxaca). Milenio, 11 December 2020. Available online: https:/ / www.milenio.com/estados/oaxaca-cndh-pide-detener-contaminacion-rio-atoyac (accessed on 26 February 2021).

83. United Nations. The Right to Water, Fact Sheet No. 35. 2010. Available online: https://www.ohchr.org/documents/publications/ factsheet35en.pdf (accessed on 1 January 2021).

84. Diario Oficial de la Federación (DOF). Ley General del Equilibrio Ecológico y la Protección al Ambiente (General Law of Ecological Equilibrium and Environmental Protection). 1988. Available online: http://www.diputados.gob.mx/LeyesBiblio/ref/lgeepa.htm (accessed on 3 January 2021).

85. Constitución Política de los Estados Unidos Mexicanos (Political Constitution of the United States of Mexico). 1917. Available online: http:/ / www.diputados.gob.mx/LeyesBiblio/ref/cpeum.htm (accessed on 2 May 2021).

86. Comisión Nacional del Agua (CONAGUA). Tarifas de Agua Potable y Saneamiento Para uso Doméstico Tipo Residencial, 2020 (Rates of Drinking Water and Sanitation for Domestic Use, 2020). Available online: http:/ / sina.conagua.gob.mx/sina/tema.php? tema=tarifas (accessed on 25 October 2021).

87. Diario Oficial de la Federación (DOF). Ley Federal de Derechos (Federal Rights Law). 1992. Available online: http://www. diputados.gob.mx/LeyesBiblio/ref/lfd.htm (accessed on 12 January 2021).

88. Diario Oficial de la Federación (DOF). NOM-127-SSA1-1994, Salud Ambiental, Agua Para uso y Consumo Humano-Límites Permisibles de Calidad y Tratamientos a Que Debe Someterse el Agua Para su Potabilización (NOM-127-SSA1-1994, Environmental Health, Water for Human Use and Consumption-Permissible Quality Limits and Treatments to Which the Water Must Be Subjected for Its Purification). 2000. Available online: http:/ / diariooficial.gob.mx/nota_detalle.php?codigo=4866379\&fecha=18 /01/1996 (accessed on 30 January 2021).

89. Incendian llantas en Protesta por Brotes de Aguas Negras (Tires Set on Fire in Protest over Sewage Outbreaks). Milenio, 13 April 2018. Available online: https://www.milenio.com/estados/incendian-llantas-protesta-brotes-aguas-negras (accessed on 25 February 2021).

90. Instituto Nacional de Estadística Geografía e Informática (INEGI). Panorama Censal de los Organismos Operadores de Agua en México (Census Overview of the Water Operating Organizations in Mexico); INEGI: Ciudad de México, Mexico, 2014. 
91. Sosa, S. Más de 100 Familias Afectadas por Fuga de Aguas Negras (More than 100 Families Affected by Sewage Leakage). Milenio, 6 November 2018. Available online: https://www.milenio.com/politica/comunidad/100-familias-afectadas-fuga-aguas-negras (accessed on 25 February 2021).

92. Pérez, F. 19 de Septiembre, el Dolor no se Olvida (September 19, the Pain Is Not Forgotten). Excélsior, 19 September 2020. Available online: https:/ / www.excelsior.com.mx/nacional/19-de-septiembre-el-dolor-no-se-olvida/1406601 (accessed on 19 February 2021).

93. Méndez, E. Sin Evidencias Para Proceder Por Descargas de Agua Residual en Acapulco (No Evidence to Proceed for Wastewater Discharges in Acapulco). Excélsior, 27 August 2021. Available online: https://www.excelsior.com.mx/nacional/sin-evidenciaspara-proceder-por-descargas-de-agua-residual-en-acapulco/1402376 (accessed on 15 February 2021).

94. Cansados de Aguas Negras Colapsan Tráfico (Tired of Wastewater). Milenio, 1 August 2018. Available online: https://www. milenio.com/estados/cansados-de-aguas-negras-colapsan-trafico (accessed on 25 February 2021).

95. Camacho, H.; Casados, J. Regulación de los Servicios de Agua Potable y Saneamiento en México (Regulation of Drinking Water and Sanitation Services in Mexico); IMTA: Jiutepec, Mexico, 2017.

96. Anglés-Hernández, M. Pobreza y exclusión social como factores determinantes para el acceso a la vivienda, al agua potable y al saneamiento (Poverty and social exclusion as determining factors for access to housing, drinking water and sanitation). In Derechos del Pueblo Mexicano. México a Través de sus Constituciones, 9th ed.; Cámara de Diputados del H. Congreso de la Unión, Ed.; Miguel Ángel Porrúa: Ciudad de México, Mexico, 2016; Volume V, pp. 401-414, ISBN 978-607-524-078-7.

97. López, A. ¿Construyen el Progreso? Un Corredor Interoceánico en Municipios sin Drenaje (Do They Build Progress? An Interoceanic Corridor in Municipalities without Drainage). El Universal, 1 July 2019. Available online: https:/ /www.eluniversal. com.mx/estados/construyen-el-progreso-un-corredor-interoceanico-en-municipios-sin-drenaje (accessed on 19 February 2021).

98. Zimmer, A.; Winkler, I.T.; De Albuquerque, C. Governing Wastewater, Curbing Pollution, and Improving Water Quality for the Realization of Human Rights. Waterlines 2014, 33, 337-356. [CrossRef]

99. International Bank for Reconstruction and Development/The World Bank. The Missing Link in Sanitation Service Delivery. A Review of Fecal Sludge Management in 12 Cities. 2014. Available online: https:/ /www.wsp.org/sites/wsp/files/publications/ WSP-Fecal-Sludge-12-City-Review-Research-Brief.pdf (accessed on 20 January 2021).

100. Instituto Nacional de los Pueblos Indígenas (INPI). Cuadro 9. Características de la Vivienda. Viviendas Particulares Habitadas por Población Indígena, Según Principales Características por Municipio, México, 2015 (Table 9. Dwelling Characteristics. Private Dwellings Inhabited by Indigenous Population, According to Main Characteristics by Municipality, Mexico, 2015). Available online: https:/ / www.gob.mx/inpi/documentos/indicadores-socioeconomicos-de-los-pueblos-indigenas-de-mexico2015 (accessed on 20 March 2021).

101. Enciso, A. Chontales Llevan Queja a CNDH por Contaminación de Laguna El Limón (Chontales File a Complaint with the National Human Rights Commission for Contamination of the El Limón Lagoon). La Jornada, 14 February 2020. Available online: https:/ / www.jornada.com.mx/ultimas / sociedad/2020/02/14/chontales-llevan-queja-a-cndh-por-contaminacion-delaguna-el-limon-7163.html (accessed on 11 February 2021).

102. Martínez, P.F.; Bandala, E.R. Issues and challenges for water supply, storm water drainage and wastewater treatment in the Mexico City metropolitan area. In Water and Cities in Latin America: Challenges for Sustainable Development; Aguilar-Barajas, I., Mahlknecht, J., Kaledin, J., Kjellén, M., Mejía-Betancourt, A., Eds.; Routledge: London, UK, 2015; pp. 109-125, ISBN 9780415730976.

103. UNEP-DHI Centre. Instrumento de Encuesta Sobre el Indicador 6.5.1 de los ODS en el país (Country Survey Iistrument for SDG Indicator 6.5.1). Available online: http:/ /iwrmdataportal.unepdhi.org/countrydatabase (accessed on 3 March 2021).

104. Galeana, A. Rechaza Acapulco Haber Vertido Aguas Negras al Mar (Acapulco Rejects Having Dumped Sewage into the Sea). Excelsior, 29 June 2020. Available online: https://www.excelsior.com.mx/nacional/rechaza-acapulco-haber-vertido-aguasnegras-al-mar/1390990 (accessed on 22 February 2021).

105. Trujillo, J. Alcaldesa de Acapulco Rechaza Descarga de Aguas Negras en la Playa (Mayor of Acapulco Rejects Discharge of Sewage on the Beach). Milenio, 17 September 2020. Available online: https:/ /www.milenio.com/estados/alcaldesa-acapulcorechaza-descarga-aguas-negras-playa (accessed on 24 February 2021).

106. Por polución de Agua Investigan en Tijuana a Constructor Ligado a Peña Nieto (A Builder Linked to Peña Nieto is Being Investigated in Tijuana for Water Pollution). La Jornada, 23 June 2020. Available online: https://www.jornada.com.mx/ultimas / estados/2020/06/23/por-polucion-de-agua-investigan-en-tijuana-a-constructor-ligado-a-pena-nieto-8051.html (accessed on 11 February 2021).

107. Aguilar, R. Presentan Denuncia Penal por Caso de Plantas Tratadoras de Aguas en Tamaulipas (Criminal Complaint for the Case of Water Treatment Plants in Tamaulipas). El Universal, 30 September 2020. Available online: https://www.eluniversal.com.mx/ estados/presentan-denuncia-penal-por-caso-de-plantas-tratadoras-de-aguas-en-tamaulipas (accessed on 15 February 2021).

108. Contreras, A. Ensucian el Río Querétaro y Autoridad no Puede Pararlos (Authority Cannot Stop Querétaro River Pollution). El Financiero, 27 May 2019. Available online: https:/ / www.elfinanciero.com.mx/bajio/ensucian-el-rio-y-autoridad-no-puedepararlos (accessed on 26 February 2021).

109. Bolaños, A. Aprueba Congreso CDMX Reformas a ley Sobre Saneamiento del Agua (Mexico City Congress Approves Reforms to the Law on Water Sanitation). La Jornada, 1 October 2020. Available online: https://www.jornada.com.mx/ultimas/capital/2020 /10/01/aprueba-congreso-cdmx-reformas-a-ley-sobre-saneamiento-del-agua-7348.html (accessed on 11 February 2021). 
110. Jiménez, H.; Canchola, A. Aumentan Penas Para Quien Contamine y Explote Aguas sin Permiso (Penalties Are Increased for Those Who Pollute and Exploit Waters without Permission). El Universal, 2 April 2019. Available online: https://www. eluniversal.com.mx/nacion/seguridad/aumentan-penas-para-quien-contamine-y-explote-aguas-sin-permiso (accessed on 13 February 2021).

111. Destituyen a Directivos por Descarga de Aguas Negras en Playa Icacos de Acapulco (Executives Dismissed for Discharge of Sewage on Icacos Beach in Acapulco). El Universal, 14 July 2020. Available online: https:/ /www.eluniversal.com.mx/estados/ destituyen-directivos-por-descarga-de-aguas-negras-en-playa-de-acapulco (accessed on 15 February 2021).

112. Hernández, A. Multa a Municipios Que No Den Recursos Para Tratar Aguas Residuales (Penalty for Municipalities That Do Not Provide Resources to Treat Wastewater). 12 July 2019. Available online: https://www.milenio.com/politica/comunidad/ multaran-a-municipios-de-no-dar-recursos-para-tratar-aguas (accessed on 23 February 2021).

113. Profepa Clausura Planta de Aguas Residuales en Tlaxcala por Contaminar Río Atoyac (Profepa Closes Wastewater Plant in Tlaxcala for Polluting the Atoyac River). Excélsior, 15 May 2018. Available online: https:/ /www.excelsior.com.mx/nacional/ profepa-clausura-planta-de-aguas-residuales-en-tlaxcala-por-contaminar-rio-atoyac/1238999 (accessed on 23 February 2021).

114. Ruiz, Z. Sapal Tratará Aguas Residuales en el Municipio (Sapal Will Treat Wastewater in the Municipality). Milenio, 22 September 2020. Available online: https:/ / www.milenio.com/politica/comunidad/sapal-tratara-aguas-residuales-en-leon (accessed on 19 February 2021).

115. Aguilar, R. Gobierno de Tamaulipas Toma Control de 3 Plantas Tratadoras de Aguas Residuales (Tamaulipas Government Takes Control of 3 Wastewater Treatment Plants). El Universal, 29 September 2020. Available online: https://www.eluniversal.com.mx/ estados/gobierno-de-tamaulipas-toma-control-de-3-plantas-tratadoras-de-aguas-residuales (accessed on 15 February 2021).

116. United Nations. Realization of the Right to Drinking Water and Sanitation Report of the Special Rapporteur, El Hadji Guissé. (E/CN.4/Sub.2/2005/25); ECOSOC: New York, NY, USA, 2005.

117. Alva, P. Toman oficinas de Simas por brote de Aguas Negras (Simas Offices Seized Due to Sewage Outbreak). Milenio, 25 September 2018. Available online: https:/ / www.milenio.com/estados/toman-oficinas-simas-brote-aguas-negras (accessed on 25 February 2021).

118. Alcalá, B. Brote de Aguas Negras Desde Hace un mes en Los Arenales (Sewage Outbreak for a Month in los Arenales). Milenio, 29 January 2019. Available online: https://www.milenio.com/estados/brote-de-aguas-negras-desde-hace-un-mes-en-los-arenales (accessed on 25 February 2021).

119. Alcalá, B. Vecinos de Nuevo Torreón Bloquean Calle Por Aguas Negras Que Entran a Sus Casas (Neighbors of Nuevo Torreón Block the Street Due to Sewage Entering Their Houses). Milenio, 21 October 2020. Available online: https://www.milenio.com/ estados/torreon-bloquean-calle-aguas-negras-entran-casas (accessed on 24 February 2021).

120. Meza, A. Protestan Vecinos por 30 Fugas de Aguas Negras en Ciudad Madero (Neighbors Protest for over 30 Sewage Leaks in Ciudad Madero). Milenio, 25 May 2019. Available online: https:/ /www.milenio.com/politica/organismos/protestan-vecinos-30 -fugas-aguas-negras-ciudad-madero (accessed on 25 February 2021).

121. López, A. Pescadores Claman por Declaratoria de Siniestro en Golfo de Tehuantepec (Fishermen Call Out for Declaration of Claim in Gulf of Tehuantepec). El Universal, 15 September 2019. Available online: https:/ / www.eluniversal.com.mx/estados / pescadores-claman-por-declaratoria-de-siniestro-en-golfo-de-tehuantepec (accessed on 12 February 2021).

122. Mota, D. Activista Denuncia a Sector Público y Privado de Contaminación en Hidalgo (Activist Denounces the Public and Private Sector for Contamination in Hidalgo). El Universal, 17 July 2019. Available online: https:/ / www.eluniversal.com.mx/estados / activista-denuncia-sector-publico-y-privado-de-contaminacion-en-hidalgo (accessed on 13 February 2021).

123. Villeda, F. Aguas Residuales, Focos de Contaminación sin Regular (Wastewater, Unregulated Sources of Contamination). Milenio, 15 June 2020. Available online: https:/ / www.milenio.com/ciencia-y-salud/tula-aguas-residuales-focos-contaminacion-regular (accessed on 23 February 2021).

124. Mota, D. Ambientalistas Exigen Agenda Para Abatir Contaminación en la Región de Tula (Environmentalists Demand Agenda to Reduce Pollution in the Tula Region). El Universal, 13 October 2020. Available online: https:/ /www.eluniversal.com.mx/estados/ ambientalistas-exigen-agenda-para-abatir-contaminacion-en-la-region-de-tula (accessed on 15 February 2021).

125. Del Castillo, A. Operar Plantas de Tratamiento, Exige el Observatorio del Agua (Operate Treatment Plants, Requires the Water Observatory). Milenio, 16 February 2018. Available online: https://www.milenio.com/estados/operar-plantas-tratamientoexige-observatorio-agua (accessed on 26 February 2021).

126. Partida, J.C. Contaminación del río Santiago Cobra Miles de Vidas (Santiago River Pollution Claims Thousands of Lives). La Jornada, 14 February 2021. Available online: https:/ / www.jornada.com.mx/notas/2021/02/14/estados/contaminacion-del-riosantiago-cobra-miles-de-vidas / (accessed on 15 February 2021).

127. Gómez, C. Ambientalistas: Urgen Proyectos Para Tratar Aguas Residuales (Environmentalists Call for Projects to Treat Wastewater). Milenio, 6 October 2019. Available online: https://www.milenio.com/politica/comunidad/tamaulipas-ambientalistaspiden-invertir-proyectos-reciclaje (accessed on 15 February 2021).

128. Servín, M. Vecinos de San Gregorio Acuerdan Agenda con Alcaldía de Xochimilco (Neighbors of San Gregorio Agree on an Agenda with the Mayor of Xochimilco). La Jornada, 13 October 2020. Available online: https://www.jornada.com.mx/ ultimas/capital/2020/10/13/vecinos-de-san-gregorio-acuerdan-agenda-con-alcaldia-de-xochimilco-9784.html (accessed on 12 February 2021). 
129. Persisten Quejas de Fuga de Aguas Negras en Torreón (Complaints of Sewage Leakage in Torreón). Milenio, 20 March 2018. Available online: https:/ / www.milenio.com/estados/persisten-quejas-fuga-aguas-negras-torreon (accessed on 26 February 2021).

130. Moreno, A. Firman Acuerdo Para Atender Desvío de Aguas Residuales a Laguna en Toluca (Agreement Is Signed to Address the Diversion of Wastewater to the Lagoon in Toluca). Milenio, 15 September 2020. Available online: https://www.milenio.com/ politica/comunidad/toluca-acuerdan-atener-desvio-aguas-residuales-laguna (accessed on 26 February 2021).

131. Zavala, S. INAI Ordena a Conagua Informar Sobre Descarga de Contaminantes en Río Lerma y Lago de Chapala (Inai Orders Conagua to Report on the Discharge of Pollutants in Lerma River and Chapala Lake). El Universal, 17 September 2020. Available online: https:/ / www.eluniversal.com.mx/nacion/inai-ordena-conagua-informar-sobre-descarga-de-contaminantes-en-riolerma-y-lago-de-chapala (accessed on 15 February 2021).

132. Lundin, M.; Molander, S.; Morrison, G.M. A set of indicators for the assessment of temporal variations in the sustainability of sanitary systems. Water Sci. Technol. 1999, 39, 235-242. [CrossRef]

133. United Nations. Water for People, Water for Life. The United Nations World Water Development Report Executive Summary; UNESCO: Paris, France, 2003.

134. Miranda, F. Exigen Sanear el río Tula y Dejar de Recibir Aguas Negras de CdMx (Call to Clean Up the Tula River and Stop Receiving Sewage from CdMx). Milenio, 29 December 2018. Available online: https:/ /www.milenio.com/estados/exigen-sanearrio-tula-dejar-recibir-aguas-negras-cdmx (accessed on 25 February 2021).

135. Reyes, A. Proyectan Evitar Descargas de Aguas Residuales en Tula-Tepeji (Plan to Avoid Wastewater Discharges in Tula-Tepeji). Milenio, 10 October 2019. Available online: https://www.milenio.com/ciencia-y-salud/medioambiente/proyectan-evitardescargas-aguas-residuales-tula-tepeji (accessed on 23 February 2021).

136. Sosa, Y. Papaloapan: Un Cauce Que Agoniza (Papaloapan: A Dying River). El Universal, 1 July 2018. Available online: https:/ / www.eluniversal.com.mx/estados/el-papaloapan-retiran-veda-un-cauce-que-agoniza (accessed on 13 February 2021).

137. Gómez, C. Arrojan al río Pánuco 600 Metros Cúbicos por Segundo de Aguas Negras (Thrown 600 Cubic Meters per Second of Sewage into the Pánuco River). Milenio, 26 September 2019. Available online: https://www.milenio.com/politica/comunidad/ rio-panuco-aguas-negras-vierten-600-m3-ambientalistas (accessed on 25 February 2021).

138. García, J.A. Estancadas Acciones por Contaminación al Carpintero (Stalled Actions Regarding Contamination to the Carpenter). Milenio, 4 June 2018. Available online: https:/ / www.milenio.com/politica/comunidad/estancadas-acciones-por-contaminacional-carpintero (accessed on 25 February 2021).

139. Gómez, C. Pandemia Aumentó Descargas de Aguas Negras a Lagunas y río en Tamaulipas (Pandemic Increased Sewage Discharges to Lagoons and Rivers in Tamaulipas). Milenio, 5 June 2020. Available online: https:/ / www.milenio.com/ciencia-ysalud/tamaulipas-pandemia-aumento-dano-ecologico-cuerpos-agua (accessed on 25 February 2021).

140. Reza, A.; Job, V. Hoteleros Vierten Aguas Negras en Arrecifes de Cozumel (Hoteliers Dump Sewage on Cozumel Reefs). Milenio, 13 October 2019. Available online: https://www.milenio.com/estados/quintana-roo-hoteleros-vierten-aguas-negras-arrecifescozumel (accessed on 25 February 2021).

141. Detectan Nueva Amenaza Para los Corales En arrecifes de Cozumel (New Threat to Corals Detected in Cozumel Reefs). El Universal, 23 July 2020. Available online: https://www.eluniversal.com.mx/estados/detectan-nueva-amenaza-para-loscorales-en-arrecifes-de-cozumel\#: \{\}:text=Colonias $\% 20 \mathrm{de} \% 20$ cianobacterias $\% 2 \mathrm{C} \% 20$ que $\% 20 \mathrm{a}$,quienes $\% 20$ advierten $\% 20$ que $\%$ 20podr\%C3\%ADan\%20aumentar (accessed on 25 February 2021).

142. Urbanismo Amenaza a Manglar de Boca del Río (Urban Planning Threatens Boca del Río Mangrove). El universal, 7 September 2019. Available online: https:/ / www.eluniversal.com.mx/estados/urbanismo-amenaza-manglar-de-boca-del-rio (accessed on 13 February 2021).

143. Contaminación Opaca la Laguna de Bacalar; Invaden Residencias 45\% de su Litoral (Pollution in Bacalar Lagoon; $45 \%$ of Its Coastline Invaded by Houses). Excérsior, 23 May 2019. Available online: https:/ /www.excelsior.com.mx/nacional/contaminacionopaca-la-laguna-de-bacalar-invaden-residencias-45-de-su-litoral/1314562 (accessed on 23 February 2021).

144. Revelan el Nivel de Corrupción con Manejo del Agua en Mexico (Corruption in Water Management in Mexico). Excélsior, 30 September 2019. Available online: https:/ / www.excelsior.com.mx/nacional/revelan-el-nivel-de-corrupcion-con-manejo-delagua-en-mexico/1339221 (accessed on 23 February 2021).

145. Méndez, E. Laxos los Criterios Para Decretar Playas Limpias en México (Lax Criteria for Decreeing Clean Beaches in Mexico). Excélsior, 18 April 2019. Available online: https://www.excelsior.com.mx/nacional/laxos-los-criterios-para-decretar-playaslimpias-en-mexico/1308264 (accessed on 23 February 2021).

146. Varillas, A. Hotel Mystique Blue en Holbox Podría ser Clausurado: Comisión del Agua de Quintana Roo (Hotel Mystique Blue in Holbox Could Be Closed: Quintana Roo Water Commission). El Universal, 5 February 2020. Available online: https://www. eluniversal.com.mx/estados/hotel-mystique-blue-podria-ser-clausuradocomision-del-agua (accessed on 15 February 2021).

147. Varillas, A. Clausura Profepa hotel en Mahahual (Profepa Closes Hotel in Mahahual). El Universal, 28 November 2018. Available online: https:/ / www.eluniversal.com.mx/estados/clausura-profepa-hotel-en-mahahual (accessed on 13 February 2021).

148. Torres, R. Cierran Empresa en Jalisco por Daño a Río Santiago (Company Is Closed in Jalisco Due to Damage to Santiago River). El Universal, 6 February 2020. Available online: https:/ / www.eluniversal.com.mx/estados/cierran-empresa-en-jalisco-por-danorio-santiago (accessed on 15 February 2021). 
149. Mota, D. Denunciarán en Países Europeos Contaminación en Hidalgo (Complaint for Contamination in Hidalgo). El Universa, 8 December 2019. Available online: https:/ / www.eluniversal.com.mx/estados/denunciaran-en-paises-europeos-contaminacionen-hidalgo (accessed on 15 February 2021).

150. Lastiri, D. CNDH Emite Recomendación por Contaminación del Río Atoyac en Guerrero (CNDH Issues Recommendation for Contamination of the Atoyac River in Guerrero). El Universal, 8 September 2019. Available online: https:/ /www.eluniversal.com. $\mathrm{mx} /$ nacion/cndh-emite-recomendacion-por-contaminacion-del-rio-atoyac-en-guerrero (accessed on 12 February 2021).

151. CIDH. CIDH Otorga Medidas Cautelares a favor de Pobladores de las Zonas Aledañas al Río Santiago en México; CIDH: Washington, DC, USA, 2020.

152. Miranda, F. Conagua Impulsa Saneamiento del río Molola en Tepic (Conagua Promotes Sanitation of the Molola River in Tepic). Milenio, 4 December 2020. Available online: https:/ / www.milenio.com/estados/tepic-conagua-impulsa-saneamiento-rio-molola (accessed on 26 February 2021). 